\title{
In search of the Bølling-Oscillation: a new high resolution pollen record from the locus classicus Lake Bølling, Denmark
}

\author{
Sascha Krüger ${ }^{1,2} \cdot$ Martin Damrath ${ }^{3}$
}

Received: 27 November 2018 / Accepted: 28 May 2019 / Published online: 11 June 2019

(c) The Author(s) 2019

\begin{abstract}
In a paper from 1942 Johannes Iversen described a warm phase prior to the Allerød warming from lake Bølling in western Denmark and thereby extended the common classification of Lateglacial biostratigraphy. Iversen's assumptions concerning the Bølling-Oscillation were based on sedimentological features and high Betula (birch) pollen values in two pollen samples prior to the onset of the Allerød warming. Questions regarding the nature of the Bølling warming later became a discussion due to the expansion of terms into different fields and especially with advances in palynology. To further refine the knowledge on the Bølling-Oscillation, Hartmut Usinger investigated the locus classicus in 1982. The method of pollen-size-frequency distribution was applied on birch pollen in order to distinguish between $B$. nana- and B. pubescens-type pollen, however, the results were never published and got lost over time. Therefore, these data are presented here and the method as described by Usinger (Pollenanalytische und stratigraphische Untersuchungen an zwei Spätglazial-Vorkommen in Schleswig-Holstein, 1975, Danm Geol Unders Årbog, 1977:5-29, 1978a, Pollen Spores 23:389-432, 1981b) is performed on the reassembled dataset again. In order to solve existing ambiguities in Lateglacial terminology, especially concerning the terms Bølling and Meiendorf, we used the data originally compiled by Usinger to discuss it against the background of the previous work by Iversen. Furthermore, the dataset enabled a comparison of different ways to determine between different Betula pollen types. The general focus is set on the distinction of Betula pollen types in order to shed light on the question of the migration of tree birches into northern Europe, especially before the Allerød warming. The results show that the dataset can immensely refine Iversen's pollen zones. A clear dominance of dwarf birch pollen during the Bølling-Oscillation is demonstrated. Furthermore, the record reveals that Iversen's assumption concerning the existence of a climatic oscillation prior to the Allerød warming can be confirmed at the locus classicus.
\end{abstract}

Keywords Bølling-Oscillation $\cdot$ Palynology $\cdot$ Lateglacial $\cdot$ Pollen-size-frequency-distribution

Communicated by T. Litt.

Electronic supplementary material The online version of this article (https://doi.org/10.1007/s00334-019-00736-3) contains supplementary material, which is available to authorized users.

Sascha Krüger

sascha.krueger@zbsa.eu

1 Centre for Baltic and Scandinavian Archaeology, Stiftung Schleswig-Holsteinische Landesmuseen, Schloss Gottorf, 24837 Schleswig, Germany

2 Institute of Prehistoric and Protohistoric Archaeology, Christian-Albrechts University Kiel, Johanna-Mestorf-Straße 2-6, 24106 Kiel, Germany

3 Faculty of Engineering, Christian-Albrechts University Kiel, Kaiserstraße 2, 24143 Kiel, Germany

\section{Introduction}

To classify periods according to key sites has been common practice in archaeology as well as in palynology. However, progressing knowledge often resulted in repeated amendments of terms and has consequently led to misinterpretations and a lack of clarity. The terminology of Lateglacial biostratigraphy in northern Europe especially underwent various revisions and adjustments. In this respect, the term $\mathrm{B} \varnothing l$ ling has been redefined almost beyond recognition, as indicated by the terms Bølling-Oscillation (Iversen 1942, 1954, 1973; van der Hammen 1951), Bølling-Zeit (Overbeck 1975), Bølling Interstadial (Usinger 1978b; van Geel et al. 1989), Bølling-Allerød complex (Usinger 1985; Friedrich et al. 2001), Bølling/Allerød Interstadial (Wooller et al. 2018) or Bølling-Allerød-Interstadial-Complex (Simikova 
and Puzachenko 2005)—referring to stratigraphy, chronozones or biozones.

In 1942, Iversen extended the common classification of Lateglacial biostratigraphy (Hartz and Milthers 1901; Jessen 1935) based on pollen analyses from Lake Bølling, Denmark. There, he found a climatic oscillation prior to the Allerød warming and named it Bølling-Oscillation (Iversen 1942). The interpretation rested on sediment features and especially on a twofold Betula pollen peak reflecting the first spread of tree birches in Denmark after the deglaciation. This interpretation led to a subdivision of the zonation by Jessen (1935). The given zone I was divided into subzone Ia (Oldest Dryas), Ib (Bølling-Oscillation) and Ic (Older Dryas), the latter representing the stadial period between the Bølling- and Allerød-Oscillation (Iversen 1947, 1954). It has been stated by Björck et al. (1998) and later by de Klerk (2004b) that terms such as oldest, older and younger are inappropriate as descriptive epithets for periodic terms. For reasons of comparability, these have still been used here, as well as the terms Dryas 1-3.

Since then, biostratigraphic classifications have been extended to terms including radiocarbon ages and climatostratigraphic elements (Mangerud et al. 1974; Donner 1995; Björck et al. 1998). The expansion of the terms (Meiendorf, Bølling, Aller $\phi$ d, Dryas) into different fields led consequently to further misunderstandings and misinterpretations. In particular Mangerud et al. (1974) intended to shed light on this ambiguity regarding terminology and suggested a chronostratigraphic scheme (for further reading and discussion see also: Usinger 1985; Donner 1995; Hoek 1997, 2009; Björck et al. 1998; de Klerk 2004b; Litt et al. 2007). There were different attempts to introduce new terms for biostratigraphy (Menke 1968; Usinger 1985, 1998; de Klerk 2004a) and for event stratigraphy (Johnson et al. 1992; Dansgaard et al. 1993; Björck et al. 1998), the latter inheriting the strength of being equally applicable to a variety of records, but the principles of Lateglacial terminology, especially concerning the term Bølling, remained rather confusing.

Furthermore, a disparity in the application of terms between countries became established. On the one hand the term Bølling describes biostratigraphically the first warmer phase of the Allerød-Interstadial (used in this paper sensu Usinger 1998) in northern Germany. The term Bølling includes the subsequent spread of Betula, encompassing tree-sized species (Usinger and Wolf 1982; Usinger 1985, 1998; Nelle and Dörfler 2008). It is equal to the Allerøda sensu Usinger (1981a) or the Juniperus-Betula nanaB. pubescens-PAZ sensu Usinger (1985). On the other hand, Bølling-Oscillation or Bølling period in Denmark is understood chronologically as an independent Interstadial equivalent to the Meiendorf-Interstadial sensu Menke (in Menke 1968; Bock et al. 1985). It is biostratigraphically characterized by increasing values of heliophilous plants ( $B$. nana, Dryas octopetala, Salix, Hippophaë, Juniperus, Artemisia) and is understood as the first warmer period of the Lateglacial (Bennike et al. 2004; Litt et al. 2007; Mortensen et al. 2011).

The pure number of publications including reinterpretations, adjustments and revisions of Lateglacial terminology make it redundant to add another definition or to further divide the existing framework. But, if there is the intention to approach the main features of the term Bølling, it is necessary to include new palynological data into the discussion. As pointed out by de Klerk (2004b, p 276) “... The most detailed pollen analysis of the Bøllings $\varnothing$ was carried out by $\mathrm{H}$. Usinger on a new core which is still unpublished with the exception of only a few pollen curves (Usinger 1985)". Since then the publication of the palynological investigation and macrofossil analysis still remained a desideratum. As Usinger targeted the distinction between $B$. nana- and $B$. pubescens-type pollen by size-frequency distribution, the results presented here shed light on the migration of tree birches in that area-a crucial point of Iversen's interpretation (Iversen 1942). Therefore, it is one objective of this paper to provide unpublished palynological and macrofossil data from Lake Bølling. Consequently, this allows for the discussion of existing ambiguities in the terminology of the Lateglacial, especially with regard to the term Bølling.

The determination of Betula pollen is essential to interpret Lateglacial pollen diagrams and to comprehend Lateglacial reforestation processes and vegetation dynamics. However, fossil European Betula pollen originate either from tree birches (Betula pendula $\mathrm{Rotн/B}$. pubescens EHRH.) or shrubby birches (Betula nana L./B. nana ssp. exilis SuKaczev/B. humilis Schrank). Based on phytogeographic considerations some of these species can be excluded spatially and temporally (Usinger 1975). In addition, Usinger (1981a) argued that Lateglacial Betula pollen precipitation predominately consisted of $B$. nana and $B$. pubescens based on multiple Lateglacial pollen and macrofossil datasets.

In the case of separating these Betula species palynologically, two different approaches are prevailing. On the one hand, there is morphological distinction (Welten 1944; Praglowski 1962, 1966; Blackmore et al. 2003). It is argued by Blackmore et al. (2003) that this approach is indeed possible requiring extremely careful comparison. However, the visual assessment of Betula pollen types has its limitations. As Firbas (1949), Birks (1968) and Mäkelä (1996) pointed out, it is hardly repeatable and inadequate as an objective research method.

On the other hand, there are attempts to separate pollen by grain-size. This method is based on the measurements of equatorial diameter or additionally of its ratio to pore height (Welten 1944; Eneroth 1951; Andersen 1961, 1970, 1980; Birks 1968; Usinger 1975; Gordon and Prentice 1977; 
Kolstrup 1982). Grain sizes of different Betula species are approximately normally distributed (Usinger 1975, 1978b, 1981a; Karlsdóttir et al. 2007). The average grain size of $B$. nana is distinctly smaller than the grain size of $B$. pubescens (B. nana, $24 \mu \mathrm{m} ; B$. pubescens ssp. pubescens, $27 \mu \mathrm{m} ; B$. pubescens ssp. tortuosa, $30 \mu \mathrm{m}$-Blackmore et al. 2003; $B$. nana, $24.5 \mu \mathrm{m} ;$ B. pubescens, $30.8 \mu \mathrm{m}-$ Beug 2004). The grain size distribution of Lateglacial Betula pollen precipitation is consequently either normally distributed (if just one species is present) or a compound distribution of two normally distributed components with different average values (Usinger 1981b).

The applicability of grain size measurements as a distinctive feature between tree and dwarf birch pollen leads to a common use of a fixed threshold (Kolstrup 1982; Karlsdóttir et al. 2007; Mortensen et al. 2011). In contrast to this method, Usinger applied the statistical method of evaluation of size-frequency distribution/approximation approach (Usinger 1975, 1978a, b, 1981b; Andersen 1980). As shown by different studies an absolute separation is not possible due to an overlap in grain-size distribution.

Beyond that it is important to note that the distinction is made between pollen types and not ultimately between species. In this respect pollen types are displayed in small CAPITALS following de Klerk (2004b) to separate them from plant taxa. However, we assume that potential errors are statistically irrelevant.

\section{Location}

Lake Bølling is situated in central Jutland, Denmark. The lake basin, roughly circular in outline and about $2 \mathrm{~km}$ in diameter, is part of a valley adjacent to the main stationary line of the Weichselian ice sheet during the last glacial maximum (Fig. 1). The valley was formed during the early Lateglacial by a meltwater stream (Brandt 1954). The area was drained in 1870 for peat cutting and agricultural purposes (Stockmarr 1975; Bennike et al. 2004) before it was restored again between 2004 and 2005. The site cored by Usinger is close to Iversen's original coring site from the 1940s and was determined by Bennike et al. (2004) as $56^{\circ} 10^{\prime} 35.4^{\prime \prime} \mathrm{N}$, $9^{\circ} 22^{\prime} 20.9^{\prime \prime} \mathrm{E}$.

\section{Material}

On the 30th of June 1981, Usinger used a modified Livingston piston-corer (Mingram et al. 2007) to extract nine different sediment cores, each with a maximum depth of four metres. Three of them were cored in an overlapping sequence to enable interruption-free analyses. Boreholes VII

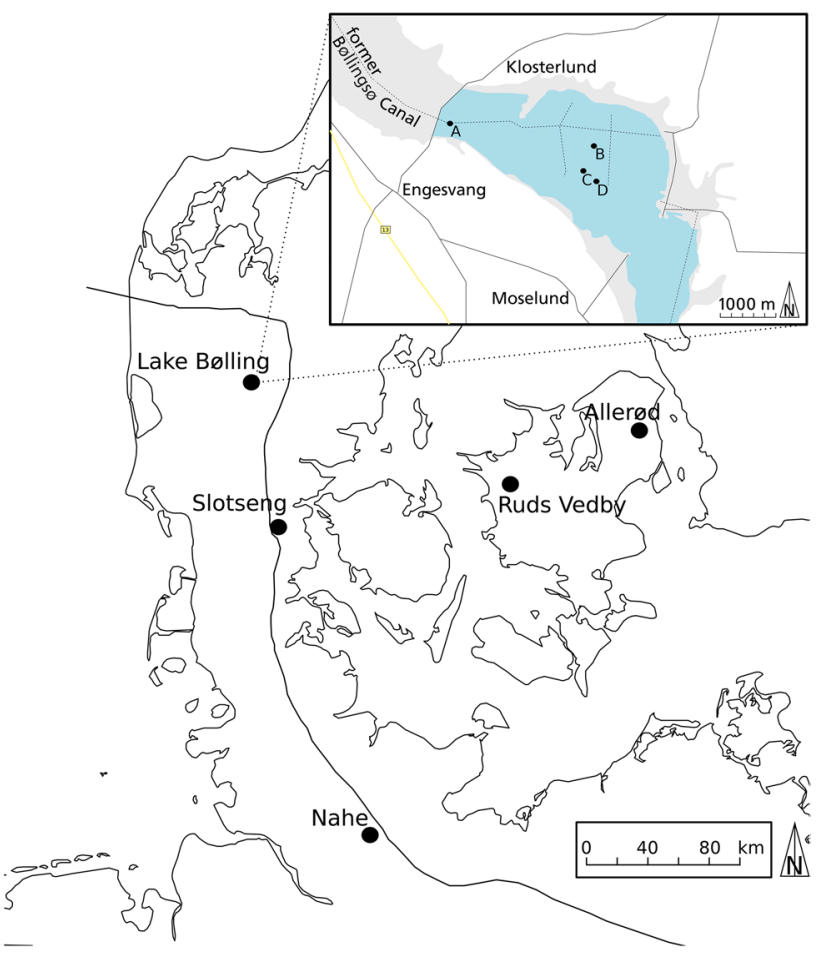

Fig. 1 Map of Denmark with important locations as mentioned in the text. Allerød-Hartz and Milthers (1901), Slotseng-Mortensen et al. (2011); Ruds Vedby-Krog (1954), Nahe-Krüger unpublished; the detailed map shows the restored Lake Bølling within the melt water valley as well as the former Bøllings $\varnothing$ canal. Location A-investigations by Stockmarr (1975), B-approximate location of the core analysed by Brandt (1954), C-excavation by Krog in 1960; D-Iversen (1942)/Bennike et al. (2004)/present study. Blue colour indicates renaturated lake area

and IX with an offset of $30 \mathrm{~cm}$ were chosen for palynological investigations.

According to a number of previous analyses of sediments from Lake Bølling the complex Lateglacial stratigraphy of the site (Iversen 1942, 1947; Stockmarr 1975) could easily be correlated with a sequence analysed by Bennike et al. (2004).

The chosen sediment sequence for pollen analysis is shown in Table 1. The sequence reaches glacial till in the bottom section at $390 \mathrm{~cm}$ depth. This is followed by irregularly layered sandy, silty and clayey gyttja up to $370 \mathrm{~cm}$ and by different layers of sand as well as clayey and silty calcareous gyttja of predominantly yellowish-grey colour up to $246 \mathrm{~cm}$. A layer of sandy and clayey gyttja with very sharp upper and lower boundaries follows up. This layer spans about four $\mathrm{cm}$ and has been interpreted by Usinger as a single event representing a hiatus. Different thick layers of calcareous gyttja interspersed with layers of fine sand and dark brown detritus gyttja are overlaying the probable hiatus (up to $165 \mathrm{~cm}$ ). These are succeeded by blackish fine 
Table 1 Lithology of Lake Bølling sediments

\begin{tabular}{ll}
\hline Depth $(\mathrm{cm})$ & Lithology \\
\hline $0-30$ & Peat \\
$30-45$ & Dark brown gyttja \\
$45-130$ & Dark grey gyttja \\
$130-165$ & Blackish fine detrital gyttja \\
$165-170$ & Grey-brown calcareous gyttja, irregularly layered with organic detritus and sand \\
$170-190$ & Grey-brown detritus gyttja/organic detritus with sand \\
$190-242$ & Grey-brown calcareous gyttja, irregularly layered with coarse sand \\
$242-246$ & Sandy, clayey gyttja (sharp boundaries; hiatus) \\
$246-280$ & Yellowish-grey calcareous gyttja \\
$280-308$ & Yellowish-grey calcareous gyttja, with numerous thin sandy (thickest at \\
& 308.0 cm) and laminated clayey layers \\
$308-332$ & Greyish clayey-silty gyttja, irregularly thin sand layers \\
$332-338$ & Clayey sand layer \\
$338-387$ & Irregularly layered sandy silty and clayey gyttja \\
$387-390$ & Coarse sand mixed with fine gravel \\
\hline
\end{tabular}

detrital gyttja $(130 \mathrm{~cm})$, dark grey and brown gyttja $(30 \mathrm{~cm})$ and finally peat.

\section{Methods}

\section{Sampling and sample treatment}

Pollen sampling and sample preparation had already been carried out in the early 1980 s by H. Usinger. He analysed a total of 89 samples that are presented here, spanning almost the whole Lateglacial and the early Holocene. Sample preparation was carried out according to standard techniques of the 1980s (Erdtman 1960; Fægri and Iversen 1964). Lycopodium spore tablets were added to each sample to calculate pollen concentrations (Stockmarr 1971). Additionally, approximately $10 \mathrm{~g}$ of sediment per sample were subjected to loss on ignition (LOI). The sediments were analysed for organic matter and $\mathrm{CaCO}_{3}$ according to the methods described by Dean (1974).

The gyttja, silt and sand layers were sampled at least at $2.5 \mathrm{~cm}$ intervals for pollen samples. The alternating thin layers of gyttja and sand (190-240 cm) that probably date to the Dryas 3 have been sampled at $5 \mathrm{~cm}$ intervals. Pollen counting was performed by $\mathrm{H}$. Usinger at a total magnification of $\times 400$ for routine counting and $\times 160$ for scanning for rare types. A total pollen sum of at least 300 TTP (total terrestrial pollen, here excluding Cyperaceae) for pollen-poor samples and $\geq 650$ TTP for average samples was achieved. Pollen grains were identified with the help of literature (Erdtman et al. 1963; Fægri and Iversen 1964) and the reference collection of the Botanical Institute at Kiel University (Germany). Pollen of thermophilous taxa such as Alnus, Corylus, Ilex aquifolium, Picea, Quercus, Tilia, Ulmus and Viscum album were regarded as rebedded/exotic if present in the Lateglacial deposits.

Additional pollen slides of each sample were visually scanned for Betula pollen by $\mathrm{H}$. Usinger. The equatorial diameter of pollen was measured to enable a separation of species by pollen-size-frequency distribution. For each sample at least 120 measurements were made by $\mathrm{H}$. Usinger.

Apart from that, samples of $10 \mathrm{~cm}^{3}$ were wet sieved at $0.4,0.2$ and $0.1 \mathrm{~mm}$ to achieve material for a macrofossil analysis. Macrofossils were identified by $\mathrm{H}$. Usinger and counted at 10- $\times 40$ magnification. The reference collection of the Botanical Institute at Kiel University was further consulted. Macrofossils are presented as numbers per $10 \mathrm{~cm}^{3}$.

The macrofossil record as well as the handwritten pollen counting and scanning sheets have been compiled again and digitalized for this study by the authors.

Here, pollen-size-frequency distributions were used to determine theoretical compound distributions of Betula species. The computation for the present study was done in Excel 2016.

The pollen diagrams were constructed using the CountPol software developed by I. Feeser, Kiel University (Germany). Percentage values shown in the diagrams are based on the total terrestrial pollen sum —on the arboreal pollen sum (AP) and pollen of non-arboreal plants from dry grounds (NAP, upland vegetation). Pollen and spores of water plants and Cyperaceae were excluded. The diagrams were imported to Inkscape (v. 0.91-1) where minor changes have been made. Zone boundaries were placed at marked changes in pollen and LOI assemblages, as well as according to the results from PEARSON's coefficient of skewness and pollen concentration.

The processing of Usinger's legacy data revealed that the preparation forms including sample weight and 
volume of each sample have been lost over time. Usinger performed the sampling consistently according to a uniform protocol (W. Dörfler personal communication). As the number of added Lycopodium spore tablets and counted spores are known, the calculation of the pollen concentrations has been obtained by assuming a uniform sample volume and weight ( $1.5 \mathrm{ml} / 1.5 \mathrm{~g}$ per sample).

\section{Determination of Betula species}

The pollen analytical determination of Betula sp. was attempted by two different methods. The first was by morphologically distinguishing a $B$. pubescens- and a $B$. nana-type (Blackmore et al. 2003; Beug 2004). Based on phytogeographic considerations, pollen and macrofossil datasets of $B$. pubescens pollen dominate the tree-birch pollen precipitation (Usinger 1981a, b), although B. pendula cannot be fully excluded. Hence, a $B$. pubescens-type is used here, including the species of $B$. pendula and $B$. pubescens (Blackmore et al. 2003; Beug 2004).

The second method was the evaluation of characteristics and parameters of pollen-size-frequency distributions.

With the first method a determination of Betula pollen based on morphologic differences was made after Terasmä (1951) as well as Erdtman et al. (1961). Generically developed pollen grains can be distinguished but the amount of intermediary pollen remains considerable, leaving space for subjective decisions (Usinger 1978b). In this respect, it was necessary to utilize the approximation approach as described by Usinger (1975, 1978b, 1981b; 'Approximation through theoretical compound distribution'). Only triporate pollen grains lying in polar view were used during the visual scanning. The pollen size was distinguished by measuring the major dimension (distance from the outside tip of the pore to the outer margin of the facing wall). For the pollen-size-frequency distribution, the pollen size was classified in $\mu \mathrm{m}$ steps. However, this microscopic work had been carried out by Usinger between 1982 and 1983 and recorded on counting sheets. Those were compiled and digitalized for the present study. In order to obtain statistically significant results (minimum of 200 Betula pollen grains, depending on the preservation), two samples were combined. Statistical parameters were used as follows:

$D$ is the modal value

$H$ is the relative frequency, $0 \leq H \leq 1$

$Q \quad$ is the relative difference of average pollen size of two species, $Q=\bar{x}_{2} / \bar{x}_{1}$ when $\bar{x}_{2}>\bar{x}_{1}$

$s \quad$ is the statistical dispersion; standard deviation

$S p \quad$ is the Pearson's coefficient of skewness, $S p=(\bar{x}-D) / s$

$V \quad$ is the coefficient of variation, $V=s / \bar{x}$ $\bar{x} \quad$ is the mean; average pollen size

\section{Pearson's coefficient of skewness}

The use of Pearson's coefficient of skewness $(S p)$ to separate $B$. nana from $B$. pubescens has already widely been discussed by Usinger (1975). The principle is based on the assumption that pollen grains feature the same size alterations when subjected to the same physical and chemical processes (Sachs 1971; Usinger 1975, 1978b, 1981b). The principle utilizes the circumstance that the modal value $D$ and the arithmetic average $\bar{x}$ do not coincide in asymmetrical distributions. In this article, the skewness of a displayed curve can reveal compound distributions, successions or changes of dominance in pollen precipitation.

\section{Approximation through theoretical compound distribution}

The algorithm is premised on the assumption that the distribution is a compound distribution of two normally distributed (and always the same) components with different mean values. Differences between the distributions are substantially based on differences in mix-ratios of the two components.

Given that the assumption is true, $\bar{x}_{1}$ and $\bar{x}_{2}$ are the mean values (average pollen sizes) and $s_{1}$ and $s_{2}$ the standard deviation of the two component distributions. The mix-ratio of the component distributions is defined by their relative frequency, for which $H_{1}+H_{2}=1$ applies. The compound distribution can be described with the function

$p(x)=\frac{H_{1}}{s_{1} \sqrt{2 \pi}} e^{-\frac{\left(x-\bar{x}_{1}\right)^{2}}{2 s_{1}^{2}}}+\frac{1-H_{1}}{s_{2} \sqrt{2 \pi}} e^{-\frac{\left(x-\bar{x}_{2}\right)^{2}}{2 s_{2}^{2}}}$,

when only $H_{1}$ is altered (Usinger 1978b, 1981b). Thereby $p(x)$ stands for pollen-frequency of size $x$. The relative frequency $H_{1}$ is determined by minimizing the mean squared error between the compound distribution and the normalized pollen-frequency-distribution $\bar{n}(x)$

$H_{1}=\underset{H_{1} \in[0,1]}{\arg \min } \sum_{x}[p(x)-\bar{n}(x)]^{2}$

In this work, $H_{1}$ is calculated through an exhaustive search with a step size of 0.01 . In addition to $H_{1}$, only $\bar{x}_{1}$ is varied with a step size of $0.1 \mu \mathrm{m}$. The second mean $\bar{x}_{2}$ results from $Q=1.19$, which is assumed to be constant (Usinger 1975; Karlsdóttir et al. 2007). The standard deviation of each component distribution results from a constant coefficient of variation $V=0.072$ (Usinger 1975, 1978b, 1981b). 


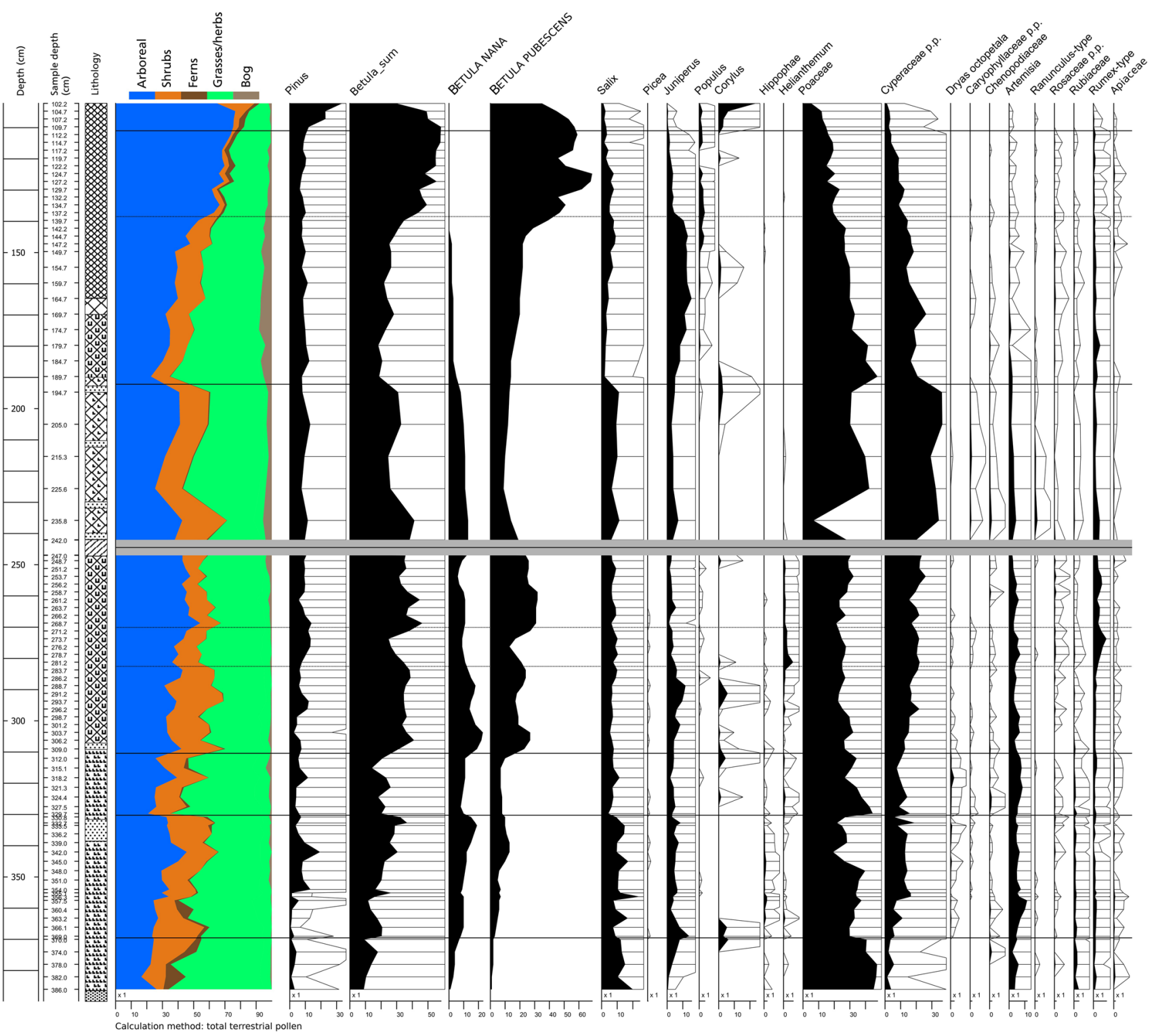

Fig. 2 Pollen percentage diagram showing selected taxa. The sum used for calculation is TTP excluding Cyperaceae. The dashed line indicates $\times 10$ exaggeration for improved reading. The grey horizontal bar indicates a hiatus

The relative frequency is used to determine the amount of B. PUBESCENS and B. NANA pollen in the total terrestrial pollen sum. Missing frequency values, due to the combination of two samples, were determined by linear interpolation. The results were smoothed with a moving average filter of length 3 .

\section{Distinction of Betula species by a fixed threshold}

The detailed and comprehensive handwritten dataset by Usinger rendered it possible to retrospectively apply a fixed threshold in order to separate Betula sp. Usinger recorded size classes of Betula pollen, by measuring the maximum diameter of the pollen grain, in $1 \mu \mathrm{m}$-steps. In this respect a fixed threshold at $21.5 \mu \mathrm{m}$ was applied, following Mortensen et al. (2011), Karlsdóttir et al. (2007) and Kolstrup (1982).

\section{Dating}

As the investigations by Usinger in 1982 did not include the dating of macrofossils, a later study by Bennike et al. (2004) aimed at obtaining datable material. Further dates were provided by Sarmaja-Korjonen et al. (2006) deriving from the same fieldwork campaign. However, the datings 


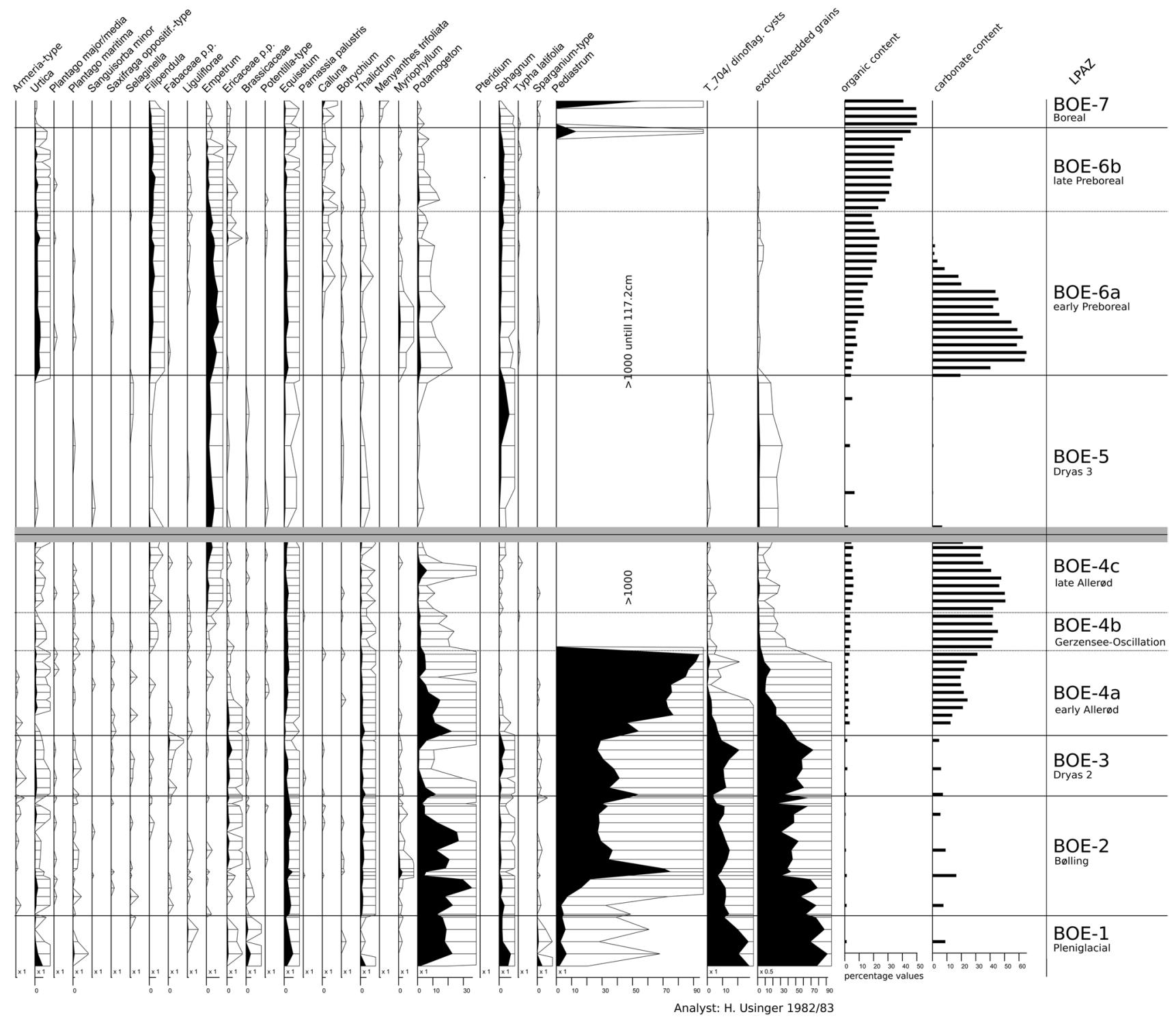

Fig. 2 (continued)

only allowed for a rather fragile age-depth model (O. Bennike personal communication). Macrofossils from Usinger's original analysis for potential new datings are unfortunately not existent. For this reason the present study neglects to set up an age-depth model and is based solely on palynostratigraphy and biostratigraphy.

\section{Results and environmental synthesis}

The pollen diagram of Lake Bølling is based on 89 pollen spectra between 102.2 and $386 \mathrm{~cm}$ below the surface. The diagram was divided into seven pollen assemblage zones (PAZ; BOE-1 to BOE-7), which further included five subzones. The general development in the pollen record is described in ESM Table 1. The pollen diagram showing percentage values calculated on TTP is shown in Fig. 2. Besides B. NANA and B. PUBESCENS curves also a Betula sum curve has been added for improved reading. A simplified concentration diagram is depicted in Fig. 3a, b.

The diagram displaying the coefficient of variation, PEARson's coefficient of skewness, the approximation approach and the fixed threshold can be seen in Fig. 4a-e. The use of the approximation approach in the uppermost samples of the record (Fig. 4c) was regarded as redundant. The sediment is of clear Holocene origin and, therefore, a calculation has not been made.

The preservation of macrofossils was predominantly good. 27 samples were analysed in total and the results are 


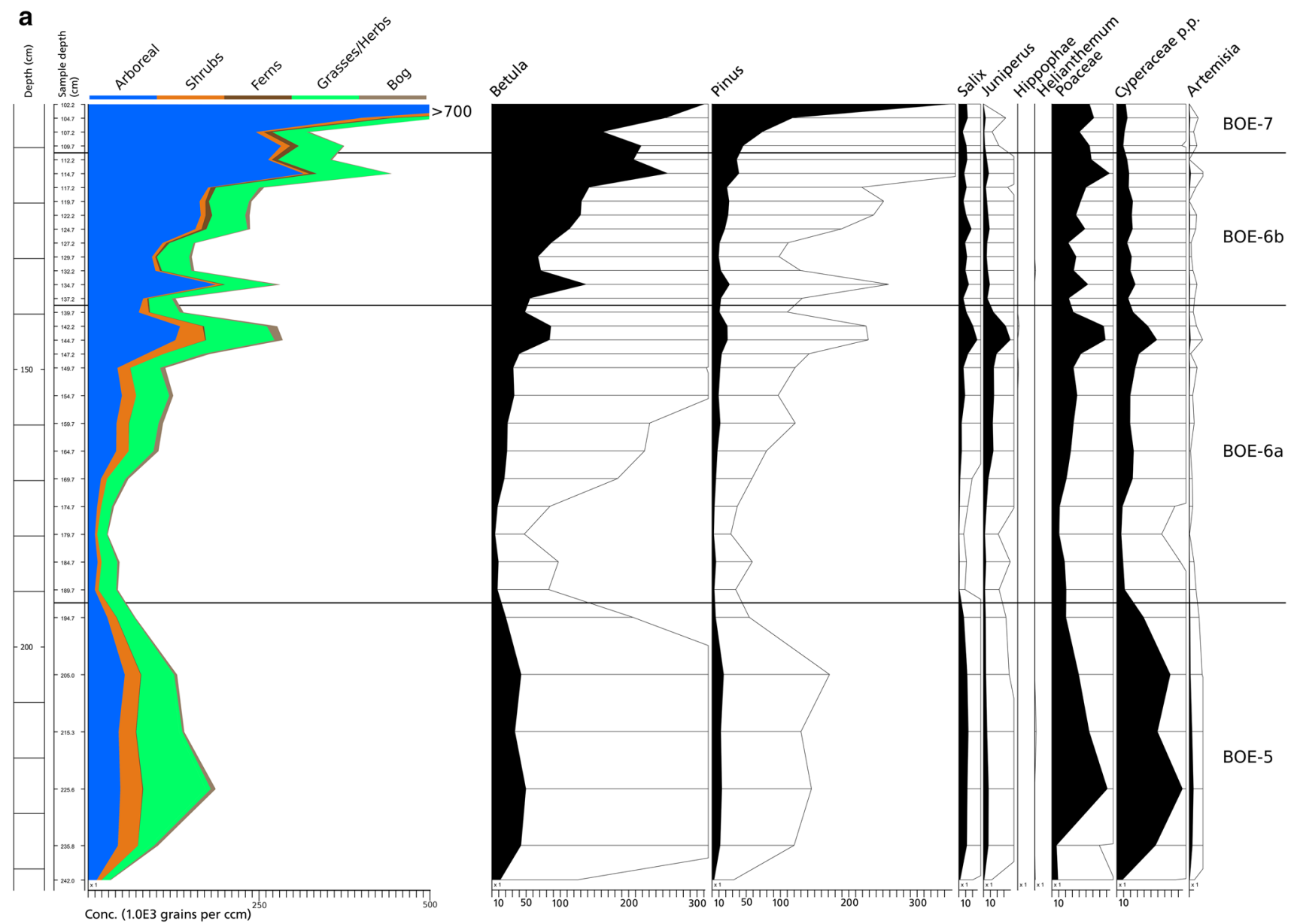

Fig. 3 a Diagram showing pollen concentration per $\mathrm{cm}^{3}$ sediment of selected taxa and sum concentration between Dryas 3 and early Boreal period. b Diagram showing pollen concentration per $\mathrm{cm}^{3}$ sedi-

given in Fig. 5. PAZs have been added at corresponding depths for improved reading.

\section{Determination of Betula species by statistical methods}

\section{Coefficient of variation and PeARSOn's skewness}

The coefficient of variation for a record of a single species would constantly remain below 0.09 as shown by Usinger (1975). However, the coefficient of variation within the first Sect. (1) of Fig. 4a remains constantly above 0.09 and in most cases even significantly above 0.11 . As suggested by Usinger $(1975,1978 b, 1981 b)$ it can be concluded that values $>0.09$ with certainty result from a compound distribution of at least two species with different average pollen sizes.

Within the second Sect. (2) the values predominantly undershoot the value 0.09 indicating that only one Betula ment of selected taxa and sum concentration between Dryas 1 and late Allerød period

species is present within the record. However, on the other hand it needs to be considered that this section displays the later Preboreal and early Boreal period (see 'Environmental synthesis' below). A mixture of B. pubescens, $B$. pendula and potential hybrids could affect the result within the early Holocene. Still, this possible source of error can be neglected, as the focus is set on the Lateglacial part of the record.

Pearson's coefficient of skewness for a record of a single species can always be characterized as approximately symmetric. In this respect asymmetry suggests a compound distribution (Usinger 1978b), indicating that all five defined sections of Fig. 4b show the presence of at least two Betula species within the record.

In a detailed study, Usinger (1975) could show that skew values above +0.3 are equivalent to a compound distribution dominated by $B$. nana, with significant participation of $B$. pubescens. To the opposite skew values below -0.15 indicate compound distributions dominated 


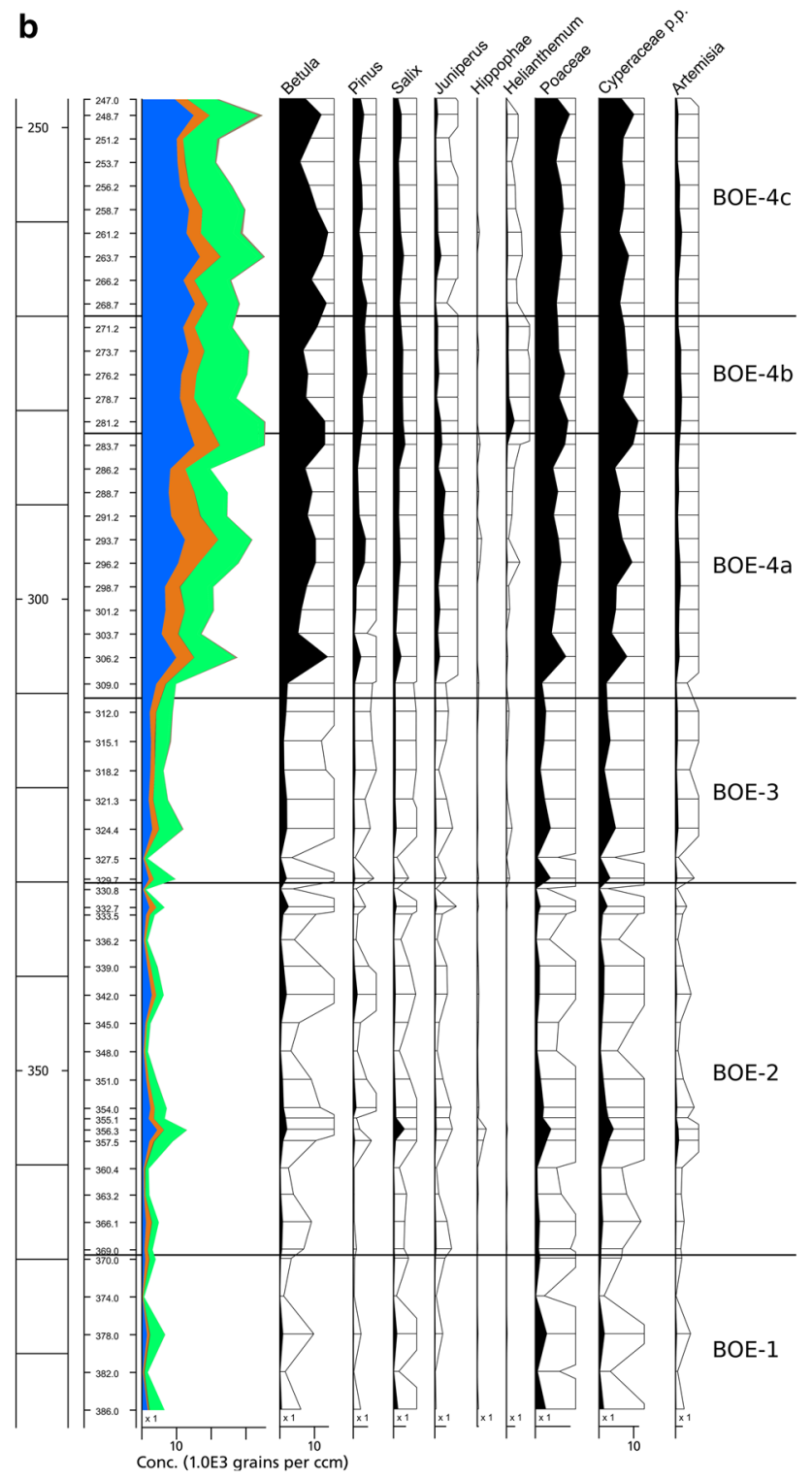

Fig. 3 (continued)

by $B$. pubescens, with significant participation of $B$. nana (Usinger 1975, 1978b; Andersen 1980).

Pearson's coefficient skewness in section one (1) of Fig. 4b significantly undershoots the value of +0.3 towards only the very end of the section. It can be inferred that the compound distribution of this section is without doubt dominated by B. NANA.

Section two (2) displays highly fluctuating values that clearly exceed and undershoot the set thresholds of -0.15 and +0.3 . Pearson's coefficient of skewness is highly dependent on the modal value $D$. $D$ does not differ distinctly in section two. The quantity of size-distributions between 21 and $25 \mu \mathrm{m}$ are almost equal. This results in a strongly varying coefficient of skewness and can be interpreted as a shift of dominance between B. NANA and B. PUBESCENS.

Within section three (3) the values have stopped fluctuating. They constantly stay below -0.15 indicating a clear dominance of B. PUBESCENS. This presumed dominance ends at the observed hiatus.

The lower part of section four (4) only contains five samples (depth 244.5-200.0 cm). An increasing tendency is obvious, indicating another possible shift in dominance, but the amount of samples is insufficient for a statistically relevant conclusion. Within the upper part of section four $(200.0-244.5 \mathrm{~cm})$ the values undershoot the threshold of -1.5 again. Considering that the blackish gyttja is of early Holocene origin, the regained dominance of B. PUBESCENS is not surprising.

Finally, section five (5) contains values that lie well between the thresholds showing no clear tendency. Considering the lithology again, this should not be interpreted as another shift in dominance between B. PUBESCENS and B. NANA. As stated above, it is more likely that the values display a compound distribution of $B$. pubescens and B. pendula (including possible hybrids), the latter being also highly relevant for early Holocene reforestation (Usinger and Wolf 1982).

\section{Determination of Betula species by approximation approach}

The method was applied in particular to focus on the earlier parts of the Lateglacial. As can be seen in Fig. $4 \mathrm{c}$ the approximation approach yielded distinct results. Especially within the assemblage zones BOE- 1 to BOE- $4 \mathrm{c}$ tendencies and dominances could be clarified.

A dominance of B. NANA within BOE-1 to BOE-2 is clear. This includes a first maximum that needs to be discussed against the background of the first Lateglacial interstadial (see 'Environmental synthesis' and 'Approaching the term Bølling'). Furthermore, the beginning of the AllerødInterstadial and a following shift in dominance between B. NANA and B. PUBESCENS can easily be noticed from the results (BOE-4a to 4c).

Potential sources of error concerning the approximation approach have been discussed in detail by Usinger (1975, 1978b). Still the question remains whether curve-fitting, interpolation and averaging will result in reliable outcomes. However, a comparison with actual pollen counts as well as macrofossils will contribute to answering that question.

It must be clear that a high resolution is imperative for conducting this application in order to detect small scale changes also. Nevertheless, the method is highly time-consuming and it is therefore recommended to only use it in case of research questions referring specifically to Betula. 


\section{Two ways of determination: a brief comparison}

The results of the determination of B. NANA by a fixed threshold (Fig. 4d) and by approximation approach (Fig. 4c) are compared in Fig. 4e. The similarities in the course of the curves and the coincidence of tendencies are apparent. This implies that the results of the approximation approach are less effected by potential sources of error than expected. However, it becomes clear that the morphological distinction (fixed threshold) yielded smaller percentages for B. NANA throughout the Lateglacial part of the diagram. In this respect, Usinger (1978b) suspected that the limits for B. NANA concerning the threshold have been set too narrowly.

As the focus of this paper is set on the earlier parts of the Lateglacial period in order to look at the relation of tree and dwarf birches it was necessary to apply the approximation approach. Only in this way was it possible to achieve a distinct result.

Whether one or the other method is applied generally draws no distinction with regard to the question of the migration of tree birches. Proof for the actual local presence of species can only be provided by macrofossils (Birks and Birks 2000) or wax lipids (Schwark et al. 2002; van den Bos et al. 2018).

\section{Environmental synthesis}

The environmental synthesis comprises the results and discussion of the pollen analysis (depicted as percentages in Fig. 2 and as concentrations in Fig. 3a, b) and the macrofossil record (Fig. 5). Palynological work by Iversen (1942), Krog (1954), Stockmarr (1975), de Klerk (2004b), Usinger (1975, 1981a, b, 1985) and Mortensen et al. (2011) is further consulted. Additionally, LOI values are incorporated, inheriting a high explanatory potential between the onset of the first Lateglacial interstadial and the end of the AllerødInterstadial (Mortensen et al. 2014a). In order to prove the presence of species, macrofossil records of previous local analyses by Brandt (1954) and Bennike et al. (2004) are included as well.

\section{BOE-1 (cf. Pleniglacial/Dryas 1) 386.0-369.5 cm}

The environmental conditions of the Lake B $\varnothing$ lling area before the onset of the first Lateglacial interstadial are characterized by diverse erosional processes. This can be inferred from high amounts of rebedded pollen grains with maxima of $90 \%$ and high abundances of dinoflagellate cysts $>20 \%$ (Bakker and van Smeerdijk 1982). Additionally, a pollen concentration below 1000 pollen grains per $\mathrm{cm}^{3}$ sediment, and irregular layers of sand embedded in a silty and clayey gyttja of $90 \%$ minerogenic content in sum suggest periglacial conditions with high aeolian activity, permafrost and solifluction.

The heterogeneous aquatic flora is composed of different species of Pediastrum, Potamogeton praelongus (Brandt 1954), P. perfoliatus and P. filiformis (Bennike et al. 2004). Those species are unlikely to have been competing with each other due to a wide ecological amplitude. The high abundance of Potamogeton sp. within the pollen spectrum as well as within the macrofossils suggest that their distribution was favoured by clear water conditions. Their ecological requirements indicate that the water levels were rather low.

At the telmatic zone of the lake Equisetum sp., Sparganium sp. and Cyperaceae were prevailing.

Some of the first pioneer species to spread on the dry raw soils were dwarf shrubs such as Salix sp. (cf. polaris, cf. herbacea) and B. nana that were also the dominating tree/ shrub pollen types as well as dry land macrofossils (Brandt 1954; Bennike et al. 2004). Towards the end of the assemblage zone, Juniperus-type pollen became abundant indicating a minor spread on the raw sandy soils. It is likely that juniper plants, if actually present, grew close to the ground. All branches that protruded beyond the winter snow cover would have been withered and eroded when the ground was frozen (Overbeck 1975). This can also be assumed for dwarf birches and willows. However, a rather sparse local vegetation can be deduced from the pollen concentration. It was generally dominated by Poaceae but also other lightdemanding herbaceous plants such as Artemisia sp., Rumex sp., Urtica sp. as well as Rubiaceae and Apiaceae.

Iversen (1942) emphasized that the high amount of reworked material may have resulted in a pure secondary pollen record originating from meltwater. Additionally, Bennike et al. (2004) also highlight a possible impairment of the interpretation caused by re-depositional processes. However, a pleniglacial interpretation of this assemblage zone is in line with vegetation records from The Netherlands (Hoek 2001; Bos et al. 2006), northern Germany (Usinger 1985; de Klerk 2002) and Denmark (Mortensen et al. 2011) probably due to a relatively sparse vegetation and thereby high erosion.

BOE-2 (cf. Meiendorf sensu Menke/Bølling-Oscillation sensu Iversen) $369.5-330.0 \mathrm{~cm}$

The variety and abundance of aquatic species in this assemblage zone mark a warming. Potamogeton praelongus, P. perfoliatus and P. filiformis are dominant, while Characeae macrofossils have also been found in large quantities (Brandt 1954; Bennike et al. 2004). Additionally, Pediastrum sp. in high abundances, Menyanthes trifoliata and Myriophyllum verticillatum are present in the pollen samples. 
Fig. 4 a The coefficient of variation according to depth including division into two sections. Red dotted line indicates threshold at 0.09; b PEARSON's coefficient of skewness according to depth including division into five sections. Red dotted lines indicate thresholds at - 0.15 and 0.3; c Approximated B. PUBESCENES and B. NANA pollen. Grey bars and grey line indicate results per sample. Green curve depicts combined samples smoothed with a moving average filter; $\mathbf{d}$ Sum curve and separate curves of B. PUBESCENES and B. NANA pollen resulting from separation by fixed threshold; e The comparison of B. NANA pollen according to approximation [green] and fixed threshold [black]

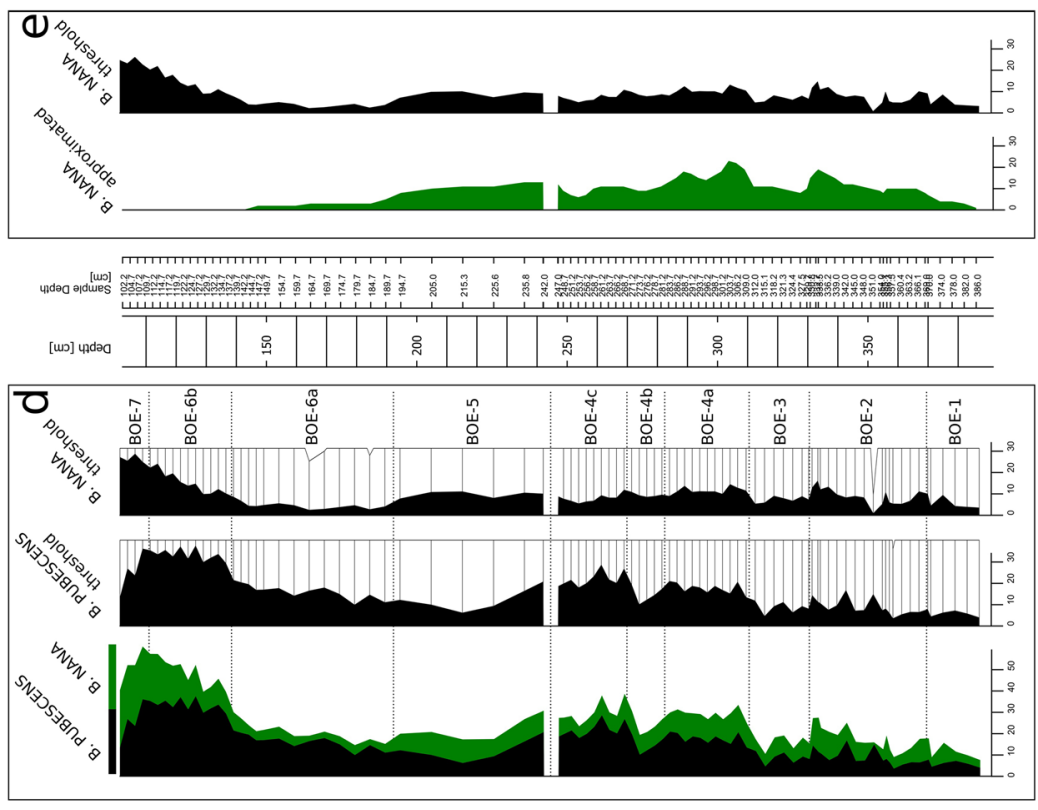

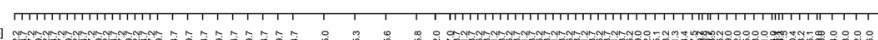

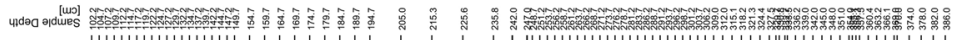

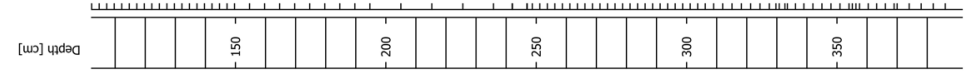

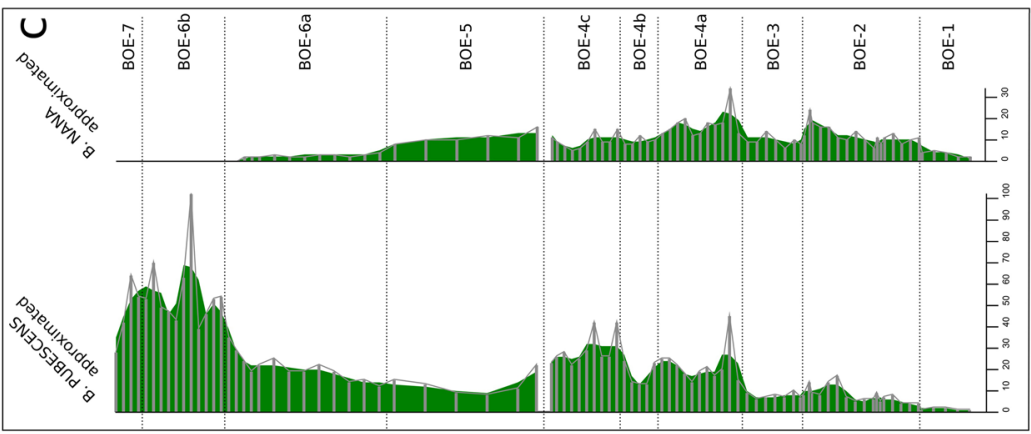

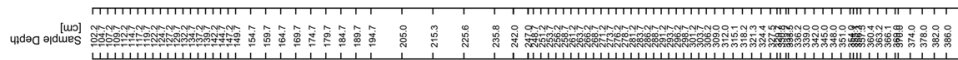
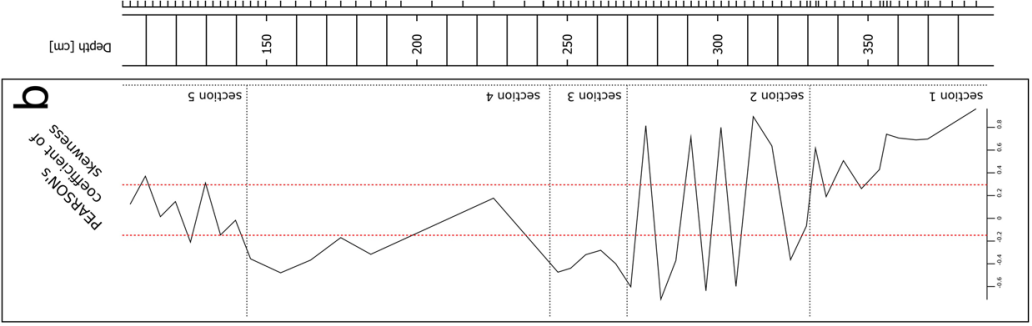

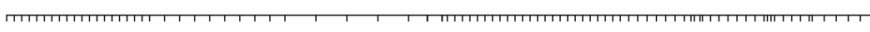

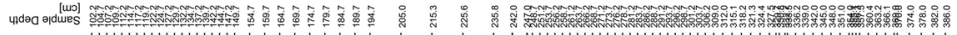
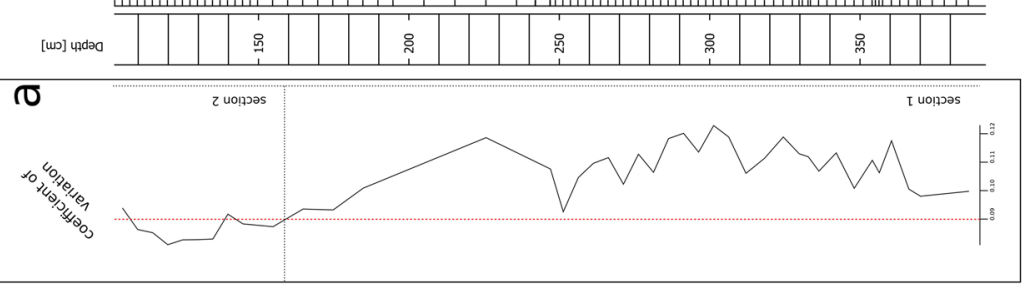

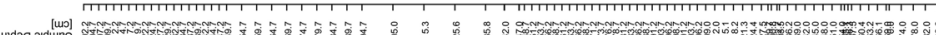

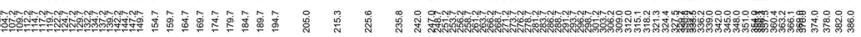

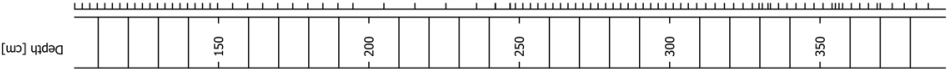




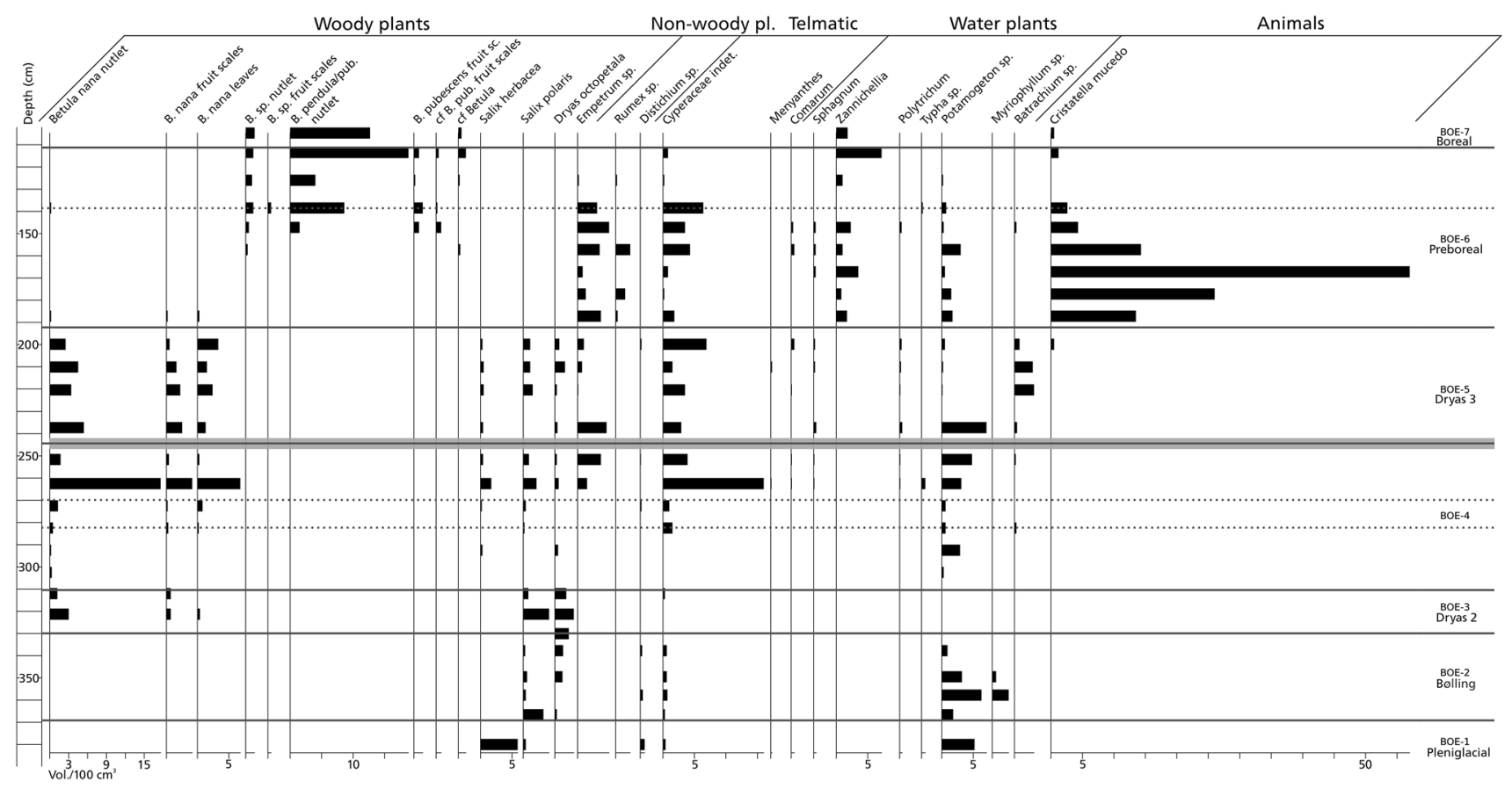

Fig. 5 Diagram showing macrofossil concentrations per $10 \mathrm{~cm}^{3}$ sediment. The taxa remains are seeds and fruits, unless otherwise specified

The aquatic ecosystem — that might have responded much faster to environmental changes than the vegetation on dry grounds (Iversen 1973; Sarmaja-Korjonen et al. 2006) could have been impacted by in-wash of minerogenic matter and rapid sedimentation as indicated by several thin sandy layers embedded in silty and clayey gyttja. The spread of aquatic species had potentially even been slowed down in this way (Bennike et al. 2004) but the overall increase in aquatic productivity could explain an increase in carbonate content of the sediment.

Still, high percentages of exotic pollen indicate unstable conditions in the area but the amount of those grains has been reduced by half. The same is valid for rearrangementindicating dinoflagellate cysts that are a major component of the marine environment. As marine influence can be excluded for this stage of the Pleistocene at the research area, their abundance within the record could be a sign of meltwater outflow or secondary deposition (Bakker and van Smeerdijk 1982). Again, this still suggests diverse environmental processes, most likely aeolian activity and meltwatererosion, but not as pronounced as before.

The percentage increase of the heliophilous Artemisia sp. as well as B. NANA and Hippophä̈ mark the beginning of assemblage zone BOE-2 and hence, of the Lateglacial (van der Hammen 1951; Iversen 1954; Menke 1968; van Geel et al. 1989; Hoek 1997; de Klerk 2008). Synchronously with the increase in variety of aquatic species, the influx of calcium carbonate in the sediment also increases. Calcareous raw soils in particular favoured the spread of
Hippophaë cf. rhamnoides in the area. Even if the distribution of Hippophaë was not as significant as in parts of northern Germany (Dätgen, Großes Moor-Aletsee 1959; Kubitzbergmoor-Usinger 1975; Eichholz-NiederungUsinger 1978b), two maxima can be observed within the PAZ. Mortensen et al. (2011) also reported on a double peak of Hippophaë rhamnoides at Slotseng, South Jutland. However, as common sea buckthorn is insect pollinated even low amounts of pollen can indicate a strong local distribution (Firbas 1949; Overbeck 1975; Søgaard et al. 2018).

Throughout the assemblage zone an increase in Betula pollen is apparent. The approximation approach revealed that B. NANA pollen was dominating. This result is supported by $B$. nana macrofossils that prove its existence in the area (Brandt 1954). Apart from that, increasing amounts of B. PUBESCENS pollen cannot be ignored. As suggested by Bennike et al. (2004) and supported by the present study (Fig. 5), macrofossils of $B$. pubescens exclusively occur in the upper parts of the sediment that can be correlated to the early Holocene. Against this background long distance transport needs to be discussed. Airborne Betula pollen easily crosses distances of $2000 \mathrm{~km}$ under favourable wind conditions (Hjelmroos 1991, 1992; Wallin et al. 1991). However the glacial refugia of tree birches can be expected much further to the south (Litt and Stebich 1999; Mortensen et al. 2014a). It is therefore presumed that the amount of recorded B. PUBESCENS pollen consists of a mixture of rebedded pollen, potentially wrongly recorded B. NANA pollen, but first and foremost of airborne pollen. The assumption contradicts the 
suggestion of Iversen (1942) who interpreted a first Betula pollen peak as the Lateglacial migration of tree birches (see 'Comparison with Iversen's diagram' below).

Still, a rather sparse local vegetation can be inferred from the pollen concentration. However, Hippophaë sp. and Juniperus sp. were present in small local populations consolidating the soil and slowing down erosional processes (de Klerk 2008). As their seeds are distributed by birds (Gillham 1970) their maximum distribution occurred before that of B. nana. Stands of $B$. nana became abundant towards the end of the assemblage zone to the disadvantage of especially Poaceae. Salix cf. polaris was also common as indicated by macrofossils (Brandt 1954; Bennike et al. 2004). An increase in the variety of herbaceous plants within BOE-2 is proven by macrofossils of Saxifraga oppositifolia, Dryas octopetala, Rumex tenuifolius, Potentilla sp., Minuartia sp., and Cerastium sp. that partly have been found within the pollen spectrum as well. Furthermore, there is pollen evidence of Helianthemum sp., Armeria sp., Plantago major/media, $P$. maritima, Caryophyllaceae, Rosaceae, Rubiaceae, Apiaceae and Fabaceae, supporting the interpretation of a vegetation with an open character.

The assignment of the spread of Hippophaë sp., Artemisia sp., Helianthemum sp. etc. to a separate phase has been suggested by e.g. Menke (1968; Merkt and Müller 1999). This is followed by a general decrease in NAP and a general Betula pollen maximum. This division could easily be made for the dataset presented and assemblage zone BOE- 2 . Nevertheless, it has been omitted as this part of the record mirrors a succession favoured by warmer conditions, here presumed to reflect one biostratigraphic unit. The results for BOE-2 show that they meet the (biostratigraphic) characteristics described for the Meiendorf-Interstadial (Bock et al. 1985) as well as for the Bølling-Oscillation (Iversen 1942). The latter did originally not include Hippophaë sp. but it was highlighted as the first pioneer shrub of Lateglacial Denmark later on (Iversen 1973). As a result, it is generally proposed here to equate the terms Meiendorf and Bølling (-biozone) as it is already common practice (Donner 1995; Bennike et al. 2004; Mortensen et al. 2011).

\section{BOE-3 (cf. Older Dryas/Dryas 2) 330.0-310.5 cm}

A general decrease in arboreal and shrub pollen contrasted by a steep increase in NAP marks the beginning of PAZ BOE-3. The amount of exotic/rebedded pollen grains increases to $>60 \%$ once again, as does the number of dinoflagellate cysts, indicating increased erosional processes in the area. Several thin layers of sand embedded in clayey-silty gyttja allude to the same process.

The aquatic ecosystem had probably been affected by colder and therewith less favourable conditions. Pollen evidence of Potamogeton sp. reduces to a minimum.
Synchronously, the macrofossil record confirms less variable aquatic biodiversity with only few finds of Potamogeton perfoliatus and P. filiformis (Brandt 1954; Bennike et al. 2004).

Pollen evidence of B. NANA, B. PUBESCEns, Salix sp. and Hippophaë sp. decreases and also the amount of B. nana macrofossils is low (Brandt 1954; Bennike et al. 2004). However, the first macrofossil of $B$. nana of the present study appears in the record. In contrast to that, a wide range of heliophilous herbs is present, including a maximum distribution of species that prefer dry and often calcareous and basic soils such as Dryas octopetala, Helianthemum sp., Artemisia sp., Armeria sp. and Rumex sp. An apparent maximum amount of Dryas octopetala macrofossils as well as few finds of Saxifraga oppositifolia, Rumex tenuifolius, Potentilla sp., Minuartia sp. and Cerastium sp. in connection with the pollen results point out that the vegetation was still dominated by light-demanding species.

The general pollen concentration almost doubled within BOE-3. The major part of the increase in concentration is determined by Poaceae. According to that, the decrease in B. nana, B. pubescens, Salix sp. and Hippophaë sp. in the percentage diagram can potentially be explained by calculation effects. A decrease in pollen percentages is not in line with a decrease in pollen concentrations. This effect has also been reported at Slotseng (Mortensen et al. 2011). This can be a result of increased local distribution of Poaceae as well as increased pollen amounts deriving from long distance transport.

BOE-4a (cf. early Allerød period) 310.5-282 cm

The onset of the Allerød-Interstadial can be detected through a variety of proxies. A change in sediment from clayey-silty gyttja to a yellowish calcareous gyttja partly showing lamination suggests less erosion and more stable conditions within the lake. A steep decrease in exotic/ rebedded pollen and dinoflagellate cysts allude to the same process.

Synchronously, a strong increase in carbonate content of the sediment is in line with a diversification of aquatic species. Especially the amounts of Characeae point to an increased precipitation of calcium carbonate (Hoek et al. 1999). Occurrences of Potamogeton filiformis, P. praelongus, P. perfoliatus, Batrachium sp. (Brandt 1954) and Callitriche hermaphroditica, as well as an increase in general Cladoceran concentrations (Bennike et al. 2004) and fair amounts of Potamogeton sp. pollen and increasing values of Pediastrum sp., indicate increased aquatic productivity through a possible growing nutrient input (Sarmaja-Korjonen et al. 2006).

The change in the environment is also reflected in pollen concentration. While the percentages remain unaltered, the overall concentration almost triples. Within the pollen 
samples maxima of B. PUBESCENS and B. NANA are significant at the beginning of the assemblage zone, the latter showing general decreasing tendencies after the maximum. Once again the spread of $B$. nana is reflected in the macrofossil record to the same extent, whereas evidence of tree birches is still lacking (Brandt 1954; Bennike et al. 2004).

Within the early Allerød period the northern limit of tree birch dispersal has expanded northwards. Pollen and macrofossil evidence suggest scattered stands of tree birches in the area of Hamburg in the early Allerød period (Overbeck 1975; Usinger 1985). In accordance with this shift also the increased influx of B. PUBESCENS pollen is assumed to derive from long distance transported pollen and not from local stands.

The total amount of arboreal and shrub pollen rises to about $50 \%$. However, the presence of Selaginella selaginoides (Bennike et al. 2004), Caryophyllaceae, Salix herbacea (Brandt 1954) and pollen evidence of Chenpodiaceae, Urtica sp., Artemisia sp., Rumex sp. and Helianthemum sp. still suggest open pioneer vegetation conditions consisting of low growing species and potentially sub-arctic conditions.

The similarities of the pollen abundances described by Usinger (1985)—cf. Juniperus-Betula nana-Betula pubescens-PAZ - for the early Allerød period are obvious. In particular, the delayed maximum of Juniperus-type pollen, which can also be observed in the diagram from Ruds Vedby, Sealand (Krog 1954), highlights an association with the early Allerød period.

The Allerød-as chronozone, climatic unit or biozoneis a period of constant fluctuations. These fluctuations have been recorded in a variety of archives such as the Greenland ice cores (Björck et al. 1998; Lowe et al. 2008; Blockley et al. 2014) as well as lake sediments from e.g. The Netherlands, Germany, Denmark and Belgium (Reinberg basin/N. Germany—de Klerk et al. 2008; Hämelsee/N. GermanyMerkt and Müller 1999; Meerfelder Maar/W. GermanyLitt and Stebich 1999; Holzmaar/W. Germany-Leroy et al. 2000; Slotseng/Denmark—Mortensen et al. 2011; Hasselø/ Denmark-Mortensen et al. 2014c; Moervaart/NW. Belgium-Bos et al. 2017; Gulickshof/S. Netherlands-Hoek et al. 1999).

It is evident that even subzone BOE-4a could potentially be further divided. Between 302 and $290 \mathrm{~cm}$ there is a decrease in B. NANA, B. PUBESCENS and in carbonate content of the sediment that correspond to short-termed increases in Poaceae, Artemisia sp. and Pinus sp. In this respect, also the following Juniperus sp. increase and decrease can be explained if one assumes this to reflect a succession with another Betula pollen maximum towards the end of assemblage zone BOE-4a. Following this, one could argue that a short termed climatic setback can potentially be found within this PAZ, which would resemble biozone Dryas $2 / \mathrm{cf}$. Older Dryas as used by Usinger (1975) or Litt et al. (2001).
This would further imply that the previous subzone including a B. NANA and B. PUBESCENS maximum could be linked to what has been called Bølling/Bölling/Boelling in German research context (Usinger 1985; Litt and Stebich 1999; Merkt and Müller 1999; Litt et al. 2001; Nelle and Dörfler 2008). However, this fluctuation is much less pronounced than the following Gerzensee-Oscillation within the pollen record. The resolution seems still too low to finally evaluate this event. Therefore, a subdivision has been neglected.

\section{BOE-4b (cf. Gerzensee-Oscillation) 282-269.9 cm}

Assemblage zone BOE- $4 \mathrm{~b}$ is characterized by a marked decrease in Betula pollen. This is, however, much more pronounced for B. PUBESCENS pollen than for B. NANA pollen. At the same time, maximum values of Pinus, Rumex sp., Artemisia sp. and Helianthemum sp. can be observed, indicating that the assemblage zone reflects the GerzenseeOscillation (Björck et al. 1998; Lotter et al. 2000) and hence, the intra-Allerød cold period (Björck et al. 1998; Andersen et al. 2000; Bennike et al. 2004; Mortensen et al. 2011).

This short-termed event is not visually reflected in the sediment but an increase in carbonate content is apparent. In how far the aquatic ecosystem was affected cannot be evaluated because the analysis of macrofossils has not been conducted on a comparable time resolution. However, pollen of Potamogeton sp. is still present and Pediastrum sp. is continuously represented in high abundances within the diagram, suggesting minor or no variation.

It can be assumed that fluctuations in pollen composition are more dependent on a change in long distance transport (Pinus, B. PUBEsCens) and in local pollen production due to the cold (Mortensen et al. 2011) than in local vegetation change. Still, an open vegetation is prevailing whereby cold and dry tolerant species as e.g. Helianthemum sp., Artemis sp. and Rumex sp. are temporarily benefitting from a shortterm temperature set-back (Björck et al. 1998).

\section{BOE-4c (cf. late Allerød period) 269.9-247 cm}

The increase of B. PUBESCENS pollen marks the beginning of assemblage zone BOE-4c. At the same time, B. NANA pollen is constantly decreasing although still being reflected in the macrofossil record (Brandt 1954; Bennike et al. 2004). Due to the lack of macrofossils, a presence of tree birches is doubted. This assumption is in line with a study by Mortensen et al. (2014a) and Bennike and Mortensen (2018), who suggested that tree birches did not migrate before the middle/late Allerød period to Denmark. Furthermore, a migration is restricted to areas where calcareous depositions of the glaciers are found forming areas of high field capacity (Mortensen et al. 2014a) — further to the east of Lake Bølling. The sandy soils around Lake Bølling 
remained a tree-less open landscape vegetated by heathland throughout the Lateglacial. It is likely that the increase in B. PUBESCENS pollen influx mainly derives from migrating tree birches to eastern Jutland that, however, did not expand into the clayey sandy soils of the Lake Bølling area (Theuerkauf and Joosten 2009).

The upland vegetation almost remained unaltered. A low growing and light-demanding plant-community consisting of Poaceae species, Artemisia sp., Helianthemum sp. and Rumex sp. dominated the landscape. Still, scattered groups of shrubs such as B. nana (Bennike et al. 2004), Salix sp. and Juniperus sp. were present. Additionally, an increasing abundance of Empetrum nigrum can be inferred from pollen and macrofossil data (Brandt 1954; Bennike et al. 2004). The dispersal of E. nigrum, an acidophilic dwarf shrub, indicates a leaching of the carbonates in the soil as well as an enrichment in humus (Bennike et al. 2004). The overall picture corresponds to the reconstruction by Mortensen et al. (2014a) who assume open heathland vegetation in the investigated area.

\section{Hiatus 247 and $242 \mathrm{~cm}$}

A layer of sandy to clayey gyttja with extremely sharp boundaries has been identified as an event causing a hiatus in the sediment record. The same is observed by Bennike et al. (2004) who report on a grey detritus gyttja with very sharp boundaries and a layer of grey well-sorted medium sand in correlating depths. As previously suggested by Usinger (1981a), such abrupt changes and the absence of transitional sediments point to a hiatus. These hiatuses have been associated with water level changes, which cannot be excluded for the coring site at Lake Bølling as well. These changes were caused by more arid climate during the Dryas 3 period (Bakke et al. 2009).This implies that reworked Allerød material needs to be considered when interpreting the assemblage zone of the following Dryas 3. The temporal extend of the hiatus is unknown.

\section{BOE-5 (cf. Younger Dryas/Dryas 3) 242-192.2 cm}

The most significant change in contrast to the previous assemblage zone is reflected in the pollen concentration. General pollen influx has increased six-fold due to erosion. This circumstance is described by Usinger (1981a) as characteristic for the hiatus between Allerød and Dryas 3 sediments. The macrofossil record likewise shows clear signs of soil erosion through the presence of in-washed Cenococcum geophilum sclerotia (Bennike et al. 2004; Krüger et al. 2017).

Synchronously with sand layers occurring within the gyttja, the abrupt decrease of calcium carbonates in the sediment is a characteristic sediment feature of the Dryas 3 (Hoek et al. 1999; van Asch et al. 2012a, b; Bos et al. 2017).

An increase in Poaceae pollen and consistently high values for Artemisia sp., Helianthemum sp. and Rumex sp. together with the frequent occurrences of Selaginella selaginoides and Dryas octopetala point to the presence of an open pioneer vegetation (Bennike et al. 2004). Furthermore, high abundances of B. NANA, Salix polaris and $S$. herbacea within the macrofossil record (Brandt 1954; Bennike et al. 2004) emphasize the level of distribution of dwarf shrubs in the landscape within the PAZ.

Large quantities of Cyperaceae indet. and Carex sp. macrofossils (Brandt 1954; Bennike et al. 2004) correspond to maximum Cyperaceae pollen values. Consequently, sedges were abundant in the telmatic zone and the closer surroundings of the lake.

\section{BOE-6a (cf. early Preboreal) $192.2-138.5 \mathrm{~cm}$}

The transition towards the Holocene is reflected in a variety of proxies. At the beginning of the assemblage zone a marked increase in carbonate content of the sediment is apparent probably suggesting higher aquatic productivity through higher temperatures. This can be inferred especially from Cladoceran analysis by Bennike et al. (2004). Again, a diversification of aquatic species can be observed in the macrofossil record, including Characeae, Potamogeton filiformis, P. perfoliatus and Zannichellia palustris (Bennike et al. 2004). The palynological evidence from Potamogeton sp., Myriophyllum sp. and Pediastrum sp. indicates the same process.

The onset of the Holocene provided more stable conditions within the lake. Less than $1 \%$ exotic/rebedded pollen grains and a lack of dinoflagellate cysts are the result of almost unimpeded sedimentation.

Within the assemblage zone a change in sediment towards a detrital gyttja is reflected in the increase of organic sediment content. This can be explained by an increase in organic production within the lake resulting from diversification and higher amounts of aquatic species.

Whilst the proportion of Poaceae is halved, other heliophilous species such as Artemisia sp. and Rumex sp. remain continuously present. Thermophilous species such as Urtica sp. and Filipendula sp. become abundant, indicating warmer climatic conditions. The disappearance of $B$. nana and the continuous lack of tree birches in the lake area promoted the spread of Juniperus sp. especially. Whether Juniperus sp. was still low-growing or reaching medium heights-as assumed for a comparable vegetation type during Dryas 3 in northern Germany with scattered trees or groups of trees/ high shrubs at favourable sites (Usinger 2004) — cannot be finally evaluated. 
The increased quantities of Empetrum-type pollen and the abundance of E. nigrum remains within the macrofossil record (Bennike et al. 2004) still indicate rather poor soil conditions. This has also been interpreted as corresponding well to a more oceanic climate (Hoek 1997; Usinger 2004; Mortensen et al. 2014b, c).

However, the Preboreal Oscillation (Behre 1967; Björck et al. 1998; Usinger 2004) cannot be seen in the record, presumably due to low sample resolution in this part of the sequence.

BOE-6b (cf. late Preboreal) $138.5-108.7 \mathrm{~cm}$

A marked change in vegetation can be assumed by the beginning of assemblage zone BOE-6b. Steeply increasing values of $\mathrm{B}$. PUBESCENS correspond to $B$. pubescens finds within the macrofossil record (Bennike et al. 2004). This is equivalent to the migration of tree birches to the Lake $\mathrm{B} \emptyset$ lling area. The assumption is supported by a significant increase in organic sediment content that has previously been interpreted as a sign of a more widespread woodland (Mortensen et al. 2014a). Zero values for B. NANA are artificial. As the sediment was of clear Holocene origin, the calculation was omitted resulting in zero values for B. NANA. $B$. nana probably grew as an understorey but the lack of macrofossils make a widespread distribution rather unlikely.

The migration of tree birches into the lake area affected the distribution of Juniperus sp. especially. A marked decrease suggests that the majority of Juniperus sp. stands were shaded out by the higher-growing birches. Poaceae were affected to the same extent. However, tree birches probably formed a relatively light open woodland with the presence of the thermophilous and heliophilous Filipendula sp. and Urtica sp.

The rising temperatures are reflected in the pollen concentrations and by increased number of species. Values more than double from 16,000 to 37,000 pollen grains per $\mathrm{cm}^{3}$ of sediment. Favourable growing conditions can be attributed to improved soil conditions and soil formation in the area, as also reflected in a decline in Empetrum-type pollen.

\section{BOE-7 (cf. early Boreal) $108.7-102.2 \mathrm{~cm}$}

Within assemblage zone BOE-7 total percentages for grasses and herbs decrease to below $10 \%$. At the same time a marked increase in Corylus-type pollen can be observed, here interpreted as the beginning of the characteristic boreal Corylus maximum (Firbas 1949; Overbeck 1975; Odgaard 1994). Furthermore, this is associated with an increase in Pinus-type pollen. Whether pine was already present or whether the rising curve just results from increased longdistance transport cannot be evaluated due to a lack of macrofossils.
A denser-growing woodland can be inferred from declining percentages of Artemisia sp., Urtica sp. and Rumex sp., only Filipendula sp. was still abundant. The species spreads even under medium shade conditions. It is also likely that the pollen originated from $F$. ulmaria that grows rather in wet meadows.

Detrital gyttja with an organic content of $\geq 30 \%$ is characteristic for early Holocene lake sediments in northern Germany and Denmark (Reinberg basin/N. Germany-de Klerk et al. 2008; Hasselø/Denmark-Mortensen et al. 2014c). This corresponds to the further increase of pollen concentrations within the assemblage zone.

\section{Approaching the term Bølling}

\section{Comparison with Iversen's diagram}

The investigation of Lake B $\varnothing$ lling by Iversen took several stages (1941—Holocene sequence; 1942—Lateglacial/early Holocene sequence; 1947—same diagram as published in 1942; 1954-Lateglacial periodic overview; 1973-simplified overview Pleistocene-Holocene). These originated from different palynological datasets based on cores from 1936, 1939 and 1946 (de Klerk 2004b). Following Bennike et al. (2004) the material presented here derives from a location very close to Iversen's original coring site. Therefore, a comparison with the dataset from 1936 (Iversen 1942) is performed.

Figure 6 displays the comparison of the two datasets. The diagram to the left is an extract from the diagram discussed above. The diagram to the right shows the Iversen dataset from 1936. Nine decisive taxa were chosen for comparison (following Iversen 1942, p 138). The calculation is based on TTP excluding Cyperaceae, as it is common practice in recent Lateglacial palynology (Mortensen et al. 2011; for further discussion see: Schütrumpf 1955; Fægri and Iversen 1964; Iversen 1973; Janssen and Ijzermans-Lutgerhorst 1973; Usinger 1975; de Klerk 2004b). It should be noted, that Pinus-type pollen grains of zone 1c in Iversen's diagram were originally not included because of being regarded as rebedded grains (Iversen 1947). Nevertheless, they are included in the displayed diagram because it cannot finally be decided whether they are the result of re-depositional processes or increased long-distance transport.

The given zonation is displayed according to original descriptions. For reasons of assumed spatial vicinity, the depths have been directly correlated. As a result, clear similarities are apparent from depth-correlation alone. This becomes even more apparent when comparing the PAZs.

The juxtaposition of the lowermost assemblage zones (BOE-1 and 1a) revealed no clear accordance. This is not surprising for three reasons. Firstly, Iversen's zone 1a consists of only two pollen samples that, secondly, have an 


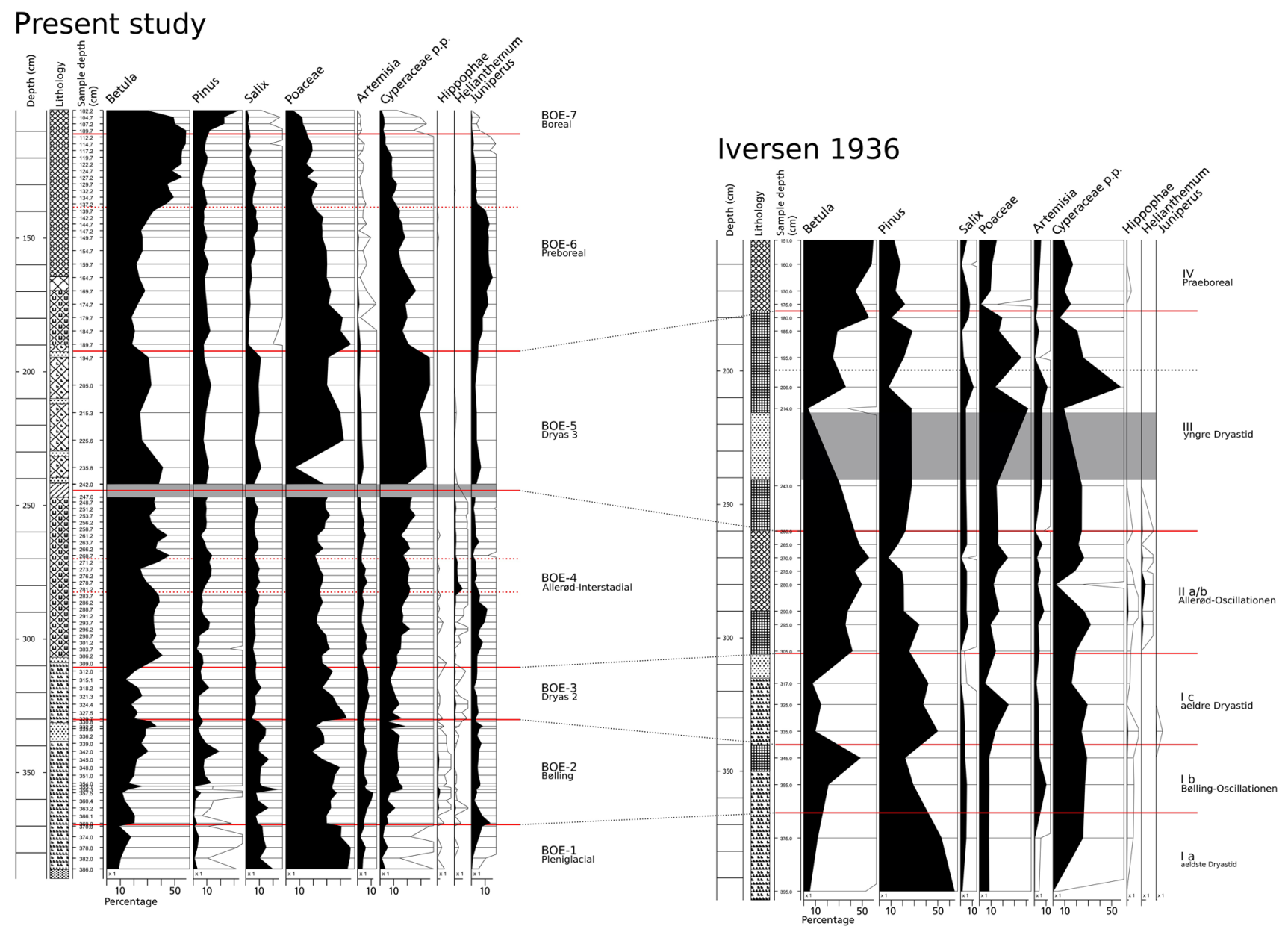

Fig. 6 Depth correlation of selected taxa from the present dataset [left] and the pollen diagram as given by Iversen (1942) from an analysis of 1936 [right]. PAZ according to original publications. Grey bars indicate hiatus

extremely low pollen sum (72 and $118 \mathrm{TTP}$ ) which is lower than the samples of BOE-1 (200-300 TTP). Thirdly, Iversen subtracted potentially rebedded pollen grains in the pollen samples below assemblage zone III (Iversen 1942), which might highly influence the displayed curves.

A correlation becomes apparent by comparing BOE-2 and zone $1 \mathrm{~b}$-Iversen's Bølling-Oscillation. Even though also zone $1 \mathrm{~b}$ only consists of two pollen samples, both diagrams show similar tendencies and percentage values. Artemisia values rise in both cases to about $10 \%$ before Betula reaches maximum values. The increase in Artemisia values is for BOE-2 and in general assumed to reflect the onset of the Lateglacial (Iversen 1947; van der Hammen 1951; Overbeck 1975; Usinger 1985).

Iversen assumed that the Betula maximum of zone $1 \mathrm{~b}$ reflects a mixture of $B$. nana and B. pubescens with a clear dominance of the latter (Iversen 1942, 1954). As discussed above, this peak in Betula mainly consists of B. NANA pollen and also the only Betula macrofossils within the record are B. nana (Brandt 1954; Bennike et al. 2004). It had been assumed before that Iversen mainly determined B. NANA pollen (Andersen 1980; Usinger 1985, 1998; de Klerk 2004b) but for the first time this can be shown for the locus classicus by the approximation approach on a detailed dataset.

It is conspicuous that Juniperus-type pollen is not present in Iversen's record with only one single exception. Working on Lake Bølling, Iversen generated three different datasets that were available for the present study. A chronological comparison of the datasets shows that total Juniperus-type pollen amounts increase over time. Therefore, it is likely to assume that Iversen did not recognize the very thin-walled and often torn Juniperus-type pollen grains in the first place, and hence they were not recorded. Difficulties in distinguishing Hippophaë pollen can be assumed to the same extent (Troels-Smith et al. 2018).

Furthermore, it has been argued for northern Germany that the maximum of B. NANA pollen is followed by a maximum of Hippophaë pollen, in sum defining the Betula-nanaHippophaë-PAZ (sensu Usinger), and hence equalling a first Lateglacial Interstadial (Usinger 1985). Based on that, 
Usinger $(1985,1998)$ reinterpreted the results of Iversen and concluded that there could not have been a pre-Allerød Interstadial sensu Iversen for Denmark. However, a comparison of Iversen's zone $1 \mathrm{~b}$ with the present study and results from the well dated site of Slotseng (Mortensen et al. 2011) — that had not been available to Usinger-shows that a slightly pronounced double maximum of Hippophä pollen before the B. NANA pollen maximum was potentially common on clayey calcareous soils within the first Lateglacial interstadial in Denmark. This would imply that Iversen did indeed find a climatic oscillation that pre-dates the Allerød period.

Within assemblage zones BOE- 3 and 1c correspondingly low values for Betula associated with a peak in Poaceae can be observed as well as decreasing Salix values. The similarity becomes even more apparent by looking at the lithology. The boundary between $1 \mathrm{c}$ and 2 was not drawn halfway between the samples (depth 317 and $305 \mathrm{~cm}$ ) as commonly done. Here, Iversen directed his attention to a layer of sand in between the samples that is also reflected in the lithology of the present study.

The Allerød period is reflected in BOE-4 and zone 2. In both cases, Betula values are fluctuating around $40 \%$. Furthermore, there is a surprisingly good match in Helianthemum. Maximum values are again found at almost the same depths (280 and $278 \mathrm{~cm}$ ).

Assemblage zones BOE-4 and BOE- 5 are separated by a hiatus of unknown temporal extent. Iversen neither displayed nor wrote about a hiatus within zone 3 . Nevertheless, the given lithology reflects a wide layer of sand that can explain the huge distance between Iversen's samples (from 214 to 243). Indeed, BOE-5 and zone 3 have independently been determined to represent the Dryas 3.

The onset of the Holocene is expressed by generally increasing values of Betula, a sharp decrease in Salix, a decrease in Artemisia and a decreasing overall tendency of Poaceae values within BOE-6. However, this would again correspond well with Iversen's diagram if the boundary between zone 3 and 4 was shifted downwards to between depths 195 and $206 \mathrm{~cm}$ (see dotted line, Fig. 6; de Klerk 2004b).

The challenge in correlating the diagrams arises from the different taxonomical and temporal resolutions. However, it can be seen that the overall correspondence between the diagrams in displayed pollen values and lithology is justified. As a result, the strength of the presented dataset lies within its ability to show the biostratigraphical units defined by Iversen (1942) in much higher resolution together with a statistical separation of Betula pollen.

Consequently, it can be inferred that Iversen's interpretation of zone $1 \mathrm{~b}$ as an independent climatic oscillation before the Allerød can be confirmed with one constraint. This would be that the $\mathrm{B} \emptyset$ lling-Oscillation sensu Iversen does not reflect the migration of tree birches, as hitherto assumed (Andersen 1980; Usinger 1985, 1998; de Klerk 2004b).

\section{The biostratigraphical term Bølling—a comment}

In 1942 Iversen made two important conclusions from his data. Firstly, he stated that there is a climatic oscillation prior to the Allerød period and that chronozone was named according to the analysed locality—Lake Bølling. Secondly, he linked his assumption to the first spread of tree birches after deglaciation - hence a biozone. Both assumptions were equally essential for Iversen's definition (Iversen 1954).

However, Usinger emphasized the latter part of Iversen's assumption. He pointed out that there could not have been a pre-Allerød-Interstadial sensu Iversen for Denmark based on comparisons to other diagrams and the migration of tree birches (Usinger 1985, 1998). Another diagram from the Lake Bølling area-Böllingsö Canal 2 (Stockmarr 1975)— corresponds to the lower sections of Iversen's diagram. Supported by disputable radiocarbon dates, Stockmarr (1975) interpreted the diagram Böllingsö Canal 2 as beginning with the Allerød-Interstadial. Years before that Krog (1954) published pollen data from Ruds Vedby - a location further away on Sealand. Therein zonal division was conducted according to Jessen (1935) and the strongly fluctuating percentages of Betula are interpreted as belonging to the Allerød (Krog 1954). Based on this, Usinger (1985) recommended a reinterpretation of the Bølling pollen zone (Bølling-Oscillation, Zone 1b) as defined by Iversen (Iversen 1942). All diagrams forming the basis for Usinger's assumption show a very low sample density at the decisive depths (Stockmarr 1975, p. 8 samples per $30 \mathrm{~cm}$; Iversen 1942 , pp. 3-4 samples per $50 \mathrm{~cm}$; Krog 1954, p. 5 samples per $20 \mathrm{~cm}$ ). Thus, it remains generally questionable whether some important changes in vegetation composition have been recorded at all. Following Usinger, the B $\varnothing$ lling pollen zone sensu Iversen would designate palynologically the early Allerød-Interstadial. This assumption would be justified if Iversen had linked the Bølling-Oscillation solely to the migration of tree birches. Nevertheless, Usinger's suggestion was resumed by Litt and Stebich (1999). It was largely accepted from that time on and partly applied for Germany (Merkt and Müller 1999; Litt et al. 2001; Nelle and Dörfler 2008).

In contrast to that, Iversen's first assumption was highlighted in Danish Lateglacial research. Here, the term is applied as resembling the first part of the Lateglacial Interstadial (Mangerud et al. 1974; Andersen 1980; Kolstrup 1982; Kolstrup and Buchardt 1982; Donner 1995; Bennike et al. 2004; Mortensen et al. 2011, 2014b, c). At the same time, it is widely accepted that the migration of birch species does not occur before the middle to late Allerød period on favourable soils (Mortensen et al. 2014a). Therefore, the rule of priority should be applied here, as Iversen was the first to 
name an oscillation prior to the Allerød that is reflected in biostratigraphy. Even if the content of the biostratigraphic term has not withstood the expansion of knowledge and hence has been altered, it is well justified to apply the term as currently done in Denmark and Scandinavia. Furthermore, it is used in exactly the same manner in e.g. France (Pastre et al. 2003; Peyron et al. 2005), Switzerland (Küttel and Lotter 1987), Poland (Majecka et al. 2018), The Netherlands (Bohncke and Wijmstra 1988; Hoek 2001, 2009), or Belgium (Bos et al. 2017, 2018). To use the term biostratigraphically as a designation for the first Lateglacial interstadial becomes even more legitimate in the context of the presented data.

The application of the term Bølling as the first part of the Allerød period in Germany is reasonable when referring only to the migration of birch species (Usinger 1985). At the same time, this is the source of confusion because of Iversen's twofold assumption concerning the Bølling-Oscillation and the introduction of the local term Meiendorf-Interval/ Interstadial for north-western Germany (Menke 1968; Bock et al. 1985). Therefore, we suggest here that terms are not altered further, but the term B $ø$ lling is abolished within the early Allerød period as currently done in German Lateglacial research contexts (Usinger 1998).

Additionally, we recommend the use of the terms Meiendorf (regionally for northern Germany as introduced by Menke (1968) and Bølling (Denmark) equally as expressions for the first interstadial of the Lateglacial. The contents of both terms correspond to the main features of the Hippophaë-Betula nana-PAZ defined by Usinger (1985). Bølling: ... er dog stadig dakket af Tundravegetation (Grosser, Halvgrasser, Artemisia, Pil og Dvargbirk). Fyr mangler. (Iversen 1942) - it is assumed that Hippophä pollen was not consistently recognised by Iversen; Meiendorf:... unter dem Bølling-Interstadial [in this case equal to Allerød-a sensu Usinger 1981b] existiert ein schwach (durch Zwergbirke und Sanddorn) gekennzeichnetes „,MeiendorfInterstadial"(Menke in Bock et al. 1985).

The utilization of two terms makes sense, as the climatic amelioration of the interstadial is reflected differently in the prevailing vegetation due to the delayed succession in the areas resulting from geographical and edaphic conditions as well as distance to plant refugia.

It is argued that the Weichselian Lateglacial can climatically be divided into three independent interstadials (GI1a, 1c and 1e; Björck et al. 1998). This division also corresponds palynostratigraphically to the Meerfelder Maar sequence (Litt and Stebich 1999) where the second interstadial period (GI-1c) is equated with the term Bølling.

Bennike et al. (2004) published ${ }^{14} \mathrm{C}$-data of macrofossils from a sediment sequence that also originates from the immediate vicinity of Iversen's original drilling site. These data thus can be correlated with the material presented here with regard to the depth. There are three radiocarbon dates for macrofossils from 330 to $332 \mathrm{~cm}$ (AAR-7442: $12,470 \pm 90$ y BP), $260-262 \mathrm{~cm}($ AAR-7443: $12,590 \pm 80$ y BP) and 366-368 cm (AAR-7444: $12,510 \pm 100$ y BP) below the surface. With respect to the depth of the presented sequence all of them are biostratigraphically part of BOE-2 and chronologically well within the given range of the first Interstadial-GI-1e (Björck et al. 1998)—and thus not within GI-1c. However, biostratigraphy is by its nature a sequence of sediment with a defined biological content, regardless of absolute dating. Clearly, it is essential to contextualize palaeoenvironmental records chronologically, but we should refrain from mixing chronozones and biozones in future research.

\section{Conclusions and outlook}

This study presents data originally compiled by Usinger to solve existing ambiguities in Lateglacial terminology especially concerning the terms Bølling and Meiendorf in order to discuss it against the background of the previous work by Iversen. A Lateglacial pollen sequence from the locus classicus Lake Bølling (Denmark) is presented spanning all Lateglacial and early Holocene biozones-with the exception of a hiatus. The study includes a separation of Betula pollen types that has been conducted in two different ways-by fixed threshold and by approximation approach. The results of the separation suggest that it is imperative to use only high resolution datasets when applying the approximation approach in order to obtain a reliable outcome. Nevertheless, the method is highly time-consuming and therefore its use is recommended exclusively in the case of research questions referring specifically to Betula. We show that there is tendentially little distinction whichever method of separation is applied.

The palynological results are discussed against the original dataset published by Iversen $(1942,1947,1954)$. The geographical proximity of Iversen's original coring site and the high resolution of the presented analysis permits the possibility of re-evaluating the origin of the Bølling-Oscillation sensu Iversen. This study confirms Iversen's interpretation of zone $1 \mathrm{~b}$ as an independent climatic oscillation before the Allerød with one constraint. This is that the BøllingOscillation sensu Iversen does not reflect the migration of local tree birches, as had been previously assumed (Usinger 1985, 1998). However, a statistical comparison with well dated Lateglacial pollen sequences should be performed the in future.

Furthermore, we recommend utilizing the terms Meiendorf (regionally for northern Germany) and Bølling (for Denmark) equally as biostratigraphical expressions for the 
first interstadial of the Lateglacial, as is an already common habit in Lateglacial palynology. To prevent further confusion the term Bølling should be abolished as a designation for the early Allerød period in German pollen diagrams.

Acknowledgements This article is part of a dissertation within project B1 (Pioneers of the North, PI: B.V. Eriksen) of the CRC 1266, Scales of Transformation. The original data were compiled by $\mathrm{H}$. Usinger in 1982 and kindly made available for study by W. Dörfler at the Institute of Prehistoric and Protohistoric Archaeology, Kiel. We are thankful to O. Bennike, P. de Klerk and especially M.F. Mortensen as well as two anonymous reviewers for valuable suggestions. Funded by the Deutsche Forschungsgemeinschaft (DFG, German Research Foundation-Projektnummer 2901391021-SFB 1266).

Open Access This article is distributed under the terms of the Creative Commons Attribution 4.0 International License (http://creativeco mmons.org/licenses/by/4.0/), which permits unrestricted use, distribution, and reproduction in any medium, provided you give appropriate credit to the original author(s) and the source, provide a link to the Creative Commons license, and indicate if changes were made.

\section{References}

Aletsee L (1959) Zur Geschichte der Moore und Wälder des nördlichen Holsteins. Barth, Leipzig

Andersen ST (1961) Vegetation and its environment in Denmark in the Early Weichselian Glacial (Last Glacial). Danmarks Geologiske Undersøgelse, 2 Række, 75. Reitzel, Kopenhagen

Andersen ST (1970) The relative pollen productivity and pollen representation of North European trees, and correction factors for tree pollen spectra. Danmarks Geologiske Undersøgelse, 2 Række, 96. Reitzel, Kopenhagen

Andersen ST (1980) Early and late Weichselian chronology and birch assemblages in Denmark. Boreas 9:53-69

Andersen CS, Björck S, Bennike O, Heinemeier J, Kromer B (2000) What do $\Delta^{14} \mathrm{C}$ changes across the Gerzensee oscillation/GI-1b event imply for deglacial oscillations? J Quat Sci 15(203):214

Bakke J et al (2009) Rapid oceanic and atmospheric changes during the Younger Dryas cold period. Nat Geosci 2:202-205. https:// doi.org/10.1038/ngeo439

Bakker M, van Smeerdijk DG (1982) A palaeoecological study of a late Holocene section from "Het Ilperveld", western Netherlands. Rev Palaeobot Palynol 36:95-163

Behre K-E (1967) The late glacial and early postglacial history of vegetation and climate in Northwestern Germany. Rev Palaeobot Palynol 4:149-161

Bennike O, Mortensen MF (2018) A multi-disciplinary macrofossil study of late glacial to early Holocene sediments from Søndre Kobberdam, Hareskovene, Denmark. Bull Geol Soc Denmark 66:113-122

Bennike O, Sarmaja-Korjonen K, Seppänen A (2004) Reinvestigation of the classic late-glacial B $\varnothing$ lling S $\varnothing$ sequence, Denmark: chronology, macrofossils, Cladocera and chydorid ephippia. J Quat Sci 19:465-478

Beug H-J (2004) Leitfaden der Pollenbestimmung für Mitteleuropa und angrenzende Gebiete. Pfeil, München

Birks HJB (1968) The Identification of Betula nana pollen. New Phytol 67:309-314

Birks HH, Birks HJB (2000) Future uses of pollen analysis must include plant macrofossils. J Biogeogr 27:31-35
Björck S, Walker MJC, Cwynar LC, Johnsen S, Knudsen KL, Lowe JJ, Wohlfarth B (1998) An event stratigraphy for the last termination in the North Atlantic region based on the Greenland ice-core record: a proposal by the INTIMATE group. J Quat Sci 13:283-292

Blackmore S, Steinmann JAJ, Hoen PP, Punt W (2003) The Northwest European Pollen Flora 65: Betulaceae and Corylaceae. Rev Palaeobot Palynol 123:28

Blockley SPE et al (2014) Tephrochronology and the extended intimate (integration of ice-core, marine and terrestrial records) event stratigraphy 8-128 ka b2k. Quat Sci Rev 106:88-100

Bock W, Menke B, Strehl E, Ziemus H (1985) Neuere Funde des Weichselspätglazials in Schleswig-Holstein. Eiszeitalt Ggw 35:161-180

Bohncke SJP, Wijmstra L (1988) Reconstruction of late-glacial lakelevel fluctuations in The Netherlands based on palaeobotanical analyses, geochemical results and pollen-density data. Boreas 17:403-425

Bos JAA, Bohncke SJP, Janssen CR (2006) Lake-level fluctuations and small-scale vegetation patterns during the late glacial in The Netherlands. J Paleolimnol 35:211-238. https://doi. org/10.1007/s10933-005-8517-0

Bos JAA, De Smedt P, Demiddele H et al (2017) Multiple oscillations during the Late-glacial as recorded in a multi-proxy, high-resolution record of the Moervaart palaeolake (NW Belgium). Quat Sci Rev 162:26-41

Bos JAA, De Smedt P, Demiddele H et al (2018) Weichselian Lateglacial environmental and vegetation development in the Moervaart palaeolake area (NW Belgium); implications for former human occupation patterns. Rev Palaeobot Palynol 248:1-14

Brandt I (1954) Late-glacial Macroscopic Plant Remains from Böllingsö. Danm Geol Unders, 2 Række 80:156-158

Dansgaard W, Johnsen SJ, Clausen HB et al (1993) Evidence for general instability of past climate from 250-kyr ice-core record. Nature 364:218-220

De Klerk P (2002) Changing vegetation patterns in the Endinger Bruch area (Vorpommern, NE Germany) during the Weichselian late-glacial and early Holocene. Rev Palaeobot Palynol 119:275-309

De Klerk P (2004a) Changes in vegetation and environment at the Late-glacial-Holocene transition in Vorpommern (Northeast Germany). In: Terberger T, Eriksen BV (eds) Hunters in a changing world: Environment and Archaeology of the Pleistocene-Holocene Transition (ca. 1100 -9000 BC) in Northern Central Europe. Internationale Archäologie-Arbeitsgemeinschaft, Symposium, Tagung, Kongress 5. Leidorf, Rahden, pp 27-42

De Klerk P (2004b) Confusing concepts in Late-glacial stratigraphy and geochronology: origin, consequences, conclusions (with special emphasis on the type locality Bøllings $\varnothing$ ). Rev Palaeobot Palynol 129:265-298

De Klerk P (2008) Patterns in vegetation and sedimentation during the Weichselian late-glacial in north-eastern Germany. J Biogeogr 35:1308-1322. https://doi.org/10.1111/j.1365-2699.2007.01866 .X

De Klerk P, Helbig H, Janke W (2008) Vegetation and environment in and around the Reinberg basin (Vorpommern, NE Germany) during the Weichselian late Pleniglacial, late-glacial, and Early Holocene. Acta Palaeobot 48:301-324

Dean WEJ (1974) Determination of carbonate and organic matter in calcareous sediments and sedimentary rocks by loss on ignition: comparison with other methods. J Sediment Petrol 44:242-248

Donner JJ (1995) The quaternary history of Scandinavia. World and regional geology 7. Cambridge University Press, Cambridge 
Eneroth O (1951) Undersökning rörande möjligheterna att i fossilt material urskilja de olika Betula-arternas pollen. Geol Fören Stockh Förh 73:343-391

Erdtman G (1960) The acetolysis method. A revised description. Svensk Botanisk Tidskrift 39:561-564

Erdtman G, Berglund B, Praglowski J (1961) An introduction to a Scandinavian pollen flora, vol 1. Almquist \& Wiksell, Stockholm

Erdtman G, Praglowski JR, Nilsson S (1963) An introduction to a Scandinavian pollen flora, vol 2. Almquist \& Wiksell, Stockholm

Fægri K, Iversen J (1964) Textbook of pollen analysis. Hafner, New York

Firbas F (1949) Spät- und nacheiszeitliche Waldgeschichte Mitteleuropas nördlich der Alpen. Allgemeine Waldgeschichte, vol 1. Fischer, Jena

Friedrich M, Kromer B, Kaiser KF, Spurk M, Hughen KA, Johnsen SJ (2001) High-resolution climate signals in the Bölling-Alleröd Interstadial (Greenland Interstadial 1) as reflected in European tree-ring chronologies compared to marine varves and ice-core records. Quat Sci Rev 20:1223-1232

Gillham ME (1970) Seed dispersal by birds. In: Perrings FE (ed) The flora of a changing Britain. Conference Reports/Botanical Society of the British Isles. Classey, Hampton, Middlesex, pp 90-98

Gordon AD, Prentice IC (1977) Numerical methods in quaternary palaeoecology. IV. Separating mixtures of morphologically similar pollen taxa. Rev Palaeobot Palynol 23:359-372

Hartz N, Milthers V (1901) Det senglaciale Ler i Allerød Teglværksgrav. Medd Dansk Geol Foren 8:31-60

Hjelmroos M (1991) Evidence of long-distance transport of Betula pollen. Grana 30:215-228

Hjelmroos M (1992) Long-distance transport of Betula pollen grains and allergic symptoms. Aerobiologia 8:231-236

Hoek WZ (1997) Late-glacial and early Holocene climate events and chronology of vegetation development in the Netherlands. Veget Hist Archaeobot 6:197-213

Hoek WZ (2001) Vegetation response to the $\sim 14.7$ and $\sim 11.5 \mathrm{ka}$ cal BP climate transitions: is vegetation lagging climate? Glob Planet Chang 30:103-115

Hoek WZ (2009) Bølling-Allerød interstadial. In: Gornitz V (ed) Encyclopedia of paleoclimatology and ancient environments. Springer, Dordrecht, pp 100-103. https://doi. org/10.1007/978-1-4020-4411-3_26

Hoek WZ, Bohncke SJP, Ganssen GM, Meijer T (1999) Late-glacial environmental changes recorded in calcareous gyttja deposits at Gulickshof, southern Netherlands. Boreas 28:416-432

Iversen J (1941) Landnam in Danmarks Stenalder: En pollenanalytisk undersøgelse over det første landbrugs indvirking paa vegetationsudviklingen. Danmarks Geologiske Undersøgelse, 2 Række, 66. Reitzel, Kopenhagen

Iversen J (1942) En pollenanalytisk Tidfæstelse af Ferskvandslagene ved Nørre Lyngby. Meddelelser fra Dansk Geologisk Forening 10:130-151

Iversen J (1947) Plantevækst, Dyreliv og Klima i det senglaciale Danmark. Geol Fören Stockh Förh 69:67-78

Iversen J (1954) The Late Glacial flora of Denmark and its relation to climate and soil. Danm Geol Unders, 2 Række 80:87-119

Iversen J (1973) Geology of Denmark 3: The development of Denmark's nature since the last glacial. Danmarks Geologiske Undersøgelse, 5 Række, 7-C. Reitzel, Kopenhagen

Janssen CR, Ijzermans-Lutgerhorst W (1973) A "local” late-glacial pollen diagram from Limburg, Netherlands. Acta Bot Neerl 22:213-220

Jessen K (1935) Archaeological dating in the history of North Jutland`s vegetation. Acta Archaeol 5:185-214

Johnson SJ et al (1992) Irregular glacial interstadials recorded in a new Greenland ice core. Nature 359:311-313
Karlsdóttir L, Thórsson ÆT, Hallsdóttir M, Sigurgeirsson A, Eysteinsson T, Anamthawat-Jónsson K (2007) Differentiating pollen of Betula species from Iceland. Grana 46:78-84

Kolstrup E (1982) Late-glacial pollen diagrams from Hjelm and Draved mose (Denmark) with a suggestion of the possibility of drought during the earlier Dryas. Rev Palaeobot Palynol 36:35-63

Kolstrup E, Buchardt B (1982) A pollen analytical investigation supported by an ${ }^{18} \mathrm{O}$-record of a late glacial lake deposit at Grænge (Denmark). Rev Palaeobot Palynol 36:205-230

Krog H (1954) Pollen analytical investigation of a C14-dated Alleröd section from Ruds Vedby. Danm Geol Unders, 5 Række 80:120-139

Krüger S, Dörfler W, Bennike O, Wolters S (2017) Life in Doggerland-palynological investigations of the environment of prehistoric hunter-gatherer societies in the North Sea Basin. Eiszeitalt Ggw 66:3-13

Küttel M, Lotter AF (1987) Vegetation und Landschaft der Zentralschweiz im Jungpleistozän. Mitt Natf Ges Luzern 29:251-272

Leroy SAG, Zolitschka B, Negendank JFW, Seret G (2000) Palynological analyses in the laminated sediment of Lake Holzmaar (Eifel, Germany): duration of Late-glacial and Preboreal biozones. Boreas 29:52-71

Litt T (2001) Correlation and synchronisation of Late-glacial continental sequences in northern central Europe based on annually laminated lacustrine sediments. Quat Sci Rev 20:1233-1249

Litt T, Stebich M (1999) Bio- and chronostratigraphy of the late-glacial in the Eifel region, Germany. Quat Int 61:5-16

Litt T, Behre K-E, Meyer K-D, Stephan H-J, Wansa S (2007) Stratigraphische Begriffe für das Quartär des norddeutschen Vereisungsgebietes. Eiszeitalt Ggw 56:59

Lotter AF, Birks HJB, Eicher U, Hofmann W, Schwander J, Wick L (2000) Younger Dryas and Allerød summer temperatures at Gerzensee (Switzerland) inferred from fossil pollen and cladoceran assemblages. Palaeogeogr Palaeoclimatol Palaeoecol 159:349-361

Lowe JJ et al (2008) Synchronisation of palaeoenvironmental events in the North Atlantic region during the Last Termination: a revised protocol recommended by the INTIMATE group. Quat Sci Rev 27:6-17

Majecka A, Balwierz Z, Forysiak J, Twardy J (2018) Eemian and Vistulian (Weichselian) development of the meltout depression on the watershed between the Mroga and Mrozyca Rivers (Central Poland) based on litholoical and pollen analysis. Quat Int 467:79-95

Mäkelä EM (1996) Size distinctions between Betula pollen types-a review. Grana 35:248-256

Mangerud J, Andersen ST, Berglund BE, Donner JJ (1974) Quaternary stratigraphy of Norden, a proposal for terminology and classification. Boreas 3:109-126

Menke B (1968) Das Spätglazial von Glüsing: Ein Beitrag zur Kenntnis der spätglazialen Vegetationsgeschichte in Westholstein. Eiszeitalt Ggw 19:73-84

Merkt J, Müller H (1999) Varve chronology and palynology of the Late-glacial in Northwest Germany from lacustrine sediments of Hämelsee in Lower Saxony. Quat Int 61:41-59

Mingram J, Negendank JFW, Brauer A, Berger D, Hendrich A, Köhler M, Usinger H (2007) Long cores from small lakes-recovering up to $100 \mathrm{~m}$-long lake sediment sequences with a high-precision rod-operated piston corer (Usinger-corer). J Paleolimnol 37:517-528

Mortensen MF, Birks HH, Christensen C (2011) Late-glacial vegetation development in Denmark-New evidence based on 
macrofossils and pollen from Slotseng, a small-scale site in southern Jutland. Quat Sci Rev 30:2534-2550

Mortensen MF, Henriksen PS, Bennike O (2014a) Living on the good soil: relationships between soils, vegetation and human settlement during the late Allerød period in Denmark. Veget Hist Archaeobot 23:195-205. https://doi.org/10.1007/s0033 4-014-0433-7)

Mortensen MF, Henriksen PS, Christensen C, Petersen PV, Olsen J (2014b) Late glacial and early Holocene vegetation development in southeast Denmark - palaeoenvironmental studies from a small lake basin close to the Palaeolithic site of Hasselø. In: Gulløv HC (ed) Northern Worlds-landscapes, interactions and dynamics. Publications from the National Museum Studies in Archaeology \& History 22. The National Museum of Denmark, Copenhagen, pp 169-188

Mortensen MF, Henriksen PS, Christensen C, Petersen PV, Olsen J (2014c) Vegetation development in south-east Denmark during the Weichselian late glacial: palaeoenvironmental studies close to the Palaeolithic site of Hasselø. Danish J Archaeol 3:33-51

Nelle O, Dörfler W (2008) A summary of the late- and post-glacial vegetation history of Schleswig-Holstein. In: Dengler J, Dolnik C, Trepel M (eds) Flora, vegetation und Naturschutz zwischen Schleswig-Holstein und Südamerika. Mitteilungen der Arbeitsgemeinschaft Geobotanik in Schleswig-Holstein und Hamburg 65, Kiel, pp 45-68

Odgaard BV (1994) The Holocene vegetation history of northern West Jutland, Denmark. Nord J Bot 14:402

Overbeck FT (1975) Botanisch-geologische Moorkunde unter besonderer Berücksichtigung der Moore Nordwestdeutschlands als Quellen zur Vegetations-, Klima- und Siedlungsgeschichte. Wachholtz, Neumünster

Pastre J-F, Limondin-Lozouet N, Leroyer C, Ponel P, Fontugne M (2003) River system evolution and environmental changes during the Late-glacial in the Paris Basin (France). Quat Sci Rev 22:2177-2188

Peyron O et al (2005) Late-glacial climatic changes in Eastern France (Lake Lautrey) from pollen, lake-levels and chironomids. Quat Res 64:197-211

Praglowski JR (1962) Notes on the pollen morphology of Swedish trees and shrubs. Grana 3:45-76

Praglowski JR (1966) On pollen size variations and the occurrence of Betula Nana in different layers of a Bog. Grana 6:528-543

Sachs L (1971) Statistische Auswertungsmethoden, vol 3. Springer, Berlin

Sarmaja-Korjonen K, Seppänen A, Bennike O (2006) Pediastrum algae from the classic late glacial B $\emptyset$ lling $S \varnothing$ site, Denmark: Response of aquatic biota to climate change. Rev Palaeobot Palynol 138:95-107

Schütrumpf R (1955) Das Spätglazial. Eiszeitalt Ggw 6:41-51

Schwark L, Zink K, Lechterbeck J (2002) Reconstruction of postglacial to early Holocene vegetation history in terrestrial Central Europe via cuticular lipid biomarkers and pollen records from lake sediments. Geology 30:463-466

Simikova AN, Puzachenko AY (2005) Palaeovegetation of Europe during the Bölling-Alleröd interstadial complex warming (12.4 10.9 ka BP). Pol Geol Inst Spec Pap 16:116-122

Søgaard K, Christensen C, Mortensen MF (2018) Pollen analyses from lake, field and beach-ridge deposits in the vicinity of the Bronze Age settlement at Bjerre Enge, Thy. In: Bech J-H, Eriksen BV, Kristiansen K (eds) Bronze age settlement and land-use in Thy, Northwest Denmark, vol 1. Jutland Archaeological Society Publications 102. Jutland Archaeological Society, Højbjerg, pp 193-221
Stockmarr J (1971) Tablets with spores used in absolute pollen analysis. Pollen Spores 13:615-621

Stockmarr J (1975) Biostratigraphic studies in Late Weichselian sediments near Böllingsö. Danm Geol Unders Årbog 1974:71-89

Terasmä J (1951) On the pollen morphology of Betula nana. Svensk Botanisk Tidskrift 45

Theuerkauf M, Joosten H (2009) Substrate dependency of Late-glacial forests in north-east Germany: untangling vegetation patterns, ecological amplitudes and pollen dispersal in the past by downscaling regional pollen. J Biogeogr 36:942-953

Troels-Smith J, Jessen K, Mortensen MF (2018) Modern pollen analysis and prehistoric beer-A lecture by Jørgen Troels-Smith, March 1977. Rev Palaeobot Palynol 259:10-20

Usinger H (1975) Pollenanalytische und stratigraphische Untersuchungen an zwei Spätglazial-Vorkommen in Schleswig-Holstein Mitteilungen der Arbeitsgemeinschaft Geobotanik in SchleswigHolstein und Hamburg 25, Kiel

Usinger H (1978a) Bölling-Interstadial und Laacher Bimstuff in einem neuen Spätglazial-Profil aus dem Vallensgård Mose/Bornholm. Mit pollen-größenstatistischer Trennung der Birken. Danm Geol Unders Årbog 1977:5-29

Usinger H (1978b) Pollen- und großrestanalytische Untersuchungen zur Frage des Bölling-Interstadials und der spätglazialen Baumbirken-Einwanderung in Schleswig-Holstein. Mit einem neuen Diagramm aus der Eichholz-Niederung bei Heiligenhafen. Schr Naturwiss Ver Schlesw-Holst 48:41-61

Usinger H (1981a) Ein weit verbreiteter Hiatus in spätglazialen Seesedimenten: Mögliche Ursache für Fehlinterpretation von Pollendiagrammen und Hinweis auf klimatisch verursachte Seespiegelbewegungen. Eiszeitalt Ggw 31:91-107

Usinger H (1981b) Zur spät-und frühen postglazialen Vegetationsgeschichte der schleswig-holsteinischen Geest nach einem Pollenund Pollendichtediagramm aus dem Esinger Moor. Pollen Spores 23:389-432

Usinger H (1985) Pollenstratigraphische, vegetations- und klimageschichtliche Gliederung des "Bölling-Alleröd-Komplexes" in Schleswig-Holstein und ihre Bedeutung für die Spätglazial Stratigraphie in benachbarten Gebieten. Flora 177:1-43

Usinger H (1998) Pollenanalytische Datierung spätpaläolithischer Fundschichten bei Ahrenshöft, Kr. Nordfriesland. Archäol Nachr aus Schles-Holst 8:50-73

Usinger H (2004) Vegetation and climate of the lowlands of northern Central Europe and adjacent areas around the Younger DryasPreboreal transition-with special emphasis on the Preboreal oscillation. In: Terberger T, Eriksen BV (eds) Hunters in a changing world: environment and archaeology of the PleistoceneHolocene Transition (ca. 1100-9000 BC) in Northern Central Europe. Internationale Archäologie-Arbeitsgemeinschaft, Symposium, Tagung, Kongress 5. Leidorf, Rahden, pp 1-26

Usinger H, Wolf A (1982) Zur vegetations- und klimageschichtlichen Gliederung des Alleröds nach Untersuchungen im Blixmoor und Kubitzbergmoor (Schleswig-Holstein). Schr Naturwiss Ver Schlesw-Holst 52:29-45

Van Asch N, Heiri O, Bohncke SJP, Hoek WZ (2012a) Climatic and environmental changes during the Weichselian Late-glacial Interstadial in the Weeterbos region, the Netherlands. Boreas 42:123-139

Van Asch N, Lutz AF, Duijkers MCH, Heiri O, Brooks SJ, Hoek WZ (2012b) Rapid climate change during the Weichselian Late-glacial in Ireland: chironomid-inferred summer temperatures from Fiddaun, Co., Galway. Palaeogeogr Palaeoclimatol Palaeoecol 315-316:1-11

Van den Bos V, Engels S, Bohncke SJP et al (2018) Late Holocene changes in vegetation and atmospheric circulation at Lake 
Uddelermeer (The Netherlands) reconstructed using lipid biomarkers and compound-specific $\delta \mathrm{D}$ analysis. J Quat Sci 33:100-111

Van der Hammen T (1951) Late-Glacial flora and periglacial phenomena in The Netherlands. Leiden

Van Geel B, Coope GR, van der Hammen T (1989) Palaeoecology and stratigraphy of the late-glacial type section at Usselo (the Netherlands). Rev Palaeobot Palynol 60:25-38, 41-42, 45-46, 48-49, 51-60, 63-64, 67-68, 75-129

Wallin J-E, Segerström U, Rosenhall L, Bergmann E, Hjelmroos M (1991) Allergic symptoms caused by long-distance transported birch pollen. Grana 30:265-268

Welten M (1944) Pollenanalytische, stratigraphische und geochronologische Untersuchungen aus dem Faulenseemoos bei Spiez.
Veröffentlichungen des Geobotanischen Institutes Rübel in Zürich 21. Huber, Bern

Wooller MJ, Saulnier-Talbot E, Potter BA et al (2018) A new terrestrial palaeoenvironmental record from the Bering Land Bridge and context for human dispersal. R Soc Open Sci. https://doi. org/10.1098/rsos. 180145

Publisher's Note Springer Nature remains neutral with regard to jurisdictional claims in published maps and institutional affiliations. 